\title{
In memoriam Simon Tibor (1926-2020)
}

\section{CSONTOS Péter ${ }^{1}$, KALAPOS Tibor ${ }^{2, \S, ~ P O ́ C S ~ T a m a ́ s ~}{ }^{3}$, PODANI János ${ }^{2, \#}$}

${ }^{1}$ Agrártudományi Kutatóközpont, Talajtani Intézet, 1022 Budapest, Herman Ottó út 15, cspeter@mail.iif.hu

${ }^{2}$ ELTE TTK, Biológiai Intézet, Növényrendszertani, Ökológiai és Elméleti Biológiai

Tanszék, 1117 Budapest, Pázmány Péter sétány 1/c, ' tibor.kalapos@ttk.elte.hu, \#podani@caesar.elte.hu

${ }^{3}$ Eszterházy Károly Egyetem, Biológiai Intézet, Növénytani és Növényélettani Tanszék, 3301 Eger, Pf. 43, pocs.tamas33@gmail.com

Elfogadva: 2021. április 20.

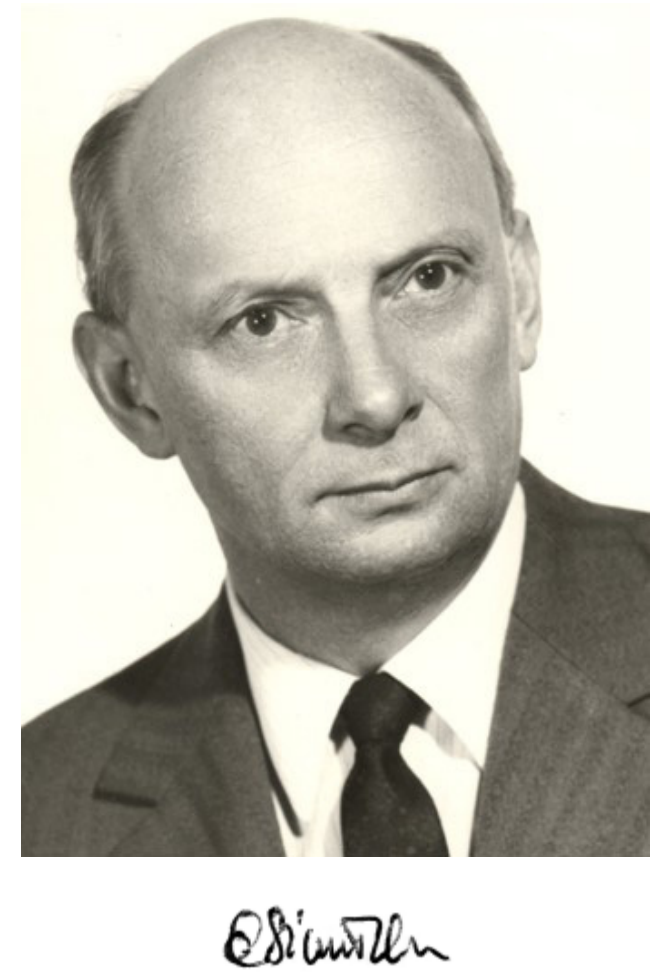

Kulcsszavak: botanika, nekrológ, bibliográfia, tudománytörténet.

A magyar biológus társadalmat mélyen megrázta a hír: 2020. november 26án hajnalban elhunyt Simon Tibor, a magyar botanika kiemelkedő egyénisége, a növények szeretetének avatott hirdetője, sokunk tanára, barátja és kollégája. Tibor Bátyánk szinte élete végéig itt volt közöttünk, páratlan aktivitással vett 
részt doktori védéseken, tanszéki rendezvényeken és kirándulásainkon - természetes volt, hogy mindig velünk van, ami még fájóbbá teszi eltávozását.

Debrecenben született 1926. július 26-án. Édesapja, Simon István nyomdász és műkedvelő énekes (akinek csodálatos basszus hangjától zengett a templom) ez utóbbi képességet fiának is továbbadta, hiszen Tibor Bátyánk közismert volt nótás kedvéről, jellegzetes orgánumáról. Édesanyja, Hriczó Mária, háztartásbeliként oltotta fiába a könyvek és a zene iránti szeretetet. Minden iskoláját a szülővárosában végezte, a Jókai utcai elemi iskolában, a Református Kollégiumban, a Fazekas Mihály Gimnáziumban és a Debreceni Magyar Királyi Tudományegyetemen. Egész életében nagy szeretettel emlékezett meg első mestereiről, elsősorban Horváthy Dezső biológia-földrajz szakos gimnáziumi tanárról, akinek szertárosként is segéd kezett, és osztályfőnökéről, Murányi Kálmánról, aki a humán tárgyak iránti vonzódását erősítette benne. Természetszeretete igen hamar, már általános iskolás korában kialakult - és főleg ez határozta meg későbbi pályafutását. Sokat kirándult a város zöldterületein és közvetlen környékén; egyformán lenyügözték az állatok, a növények és az életközösségek is, mint például a szikes rétek növényzete. Középiskolás éveinek egyik nagy élménye volt, amikor az iskola szervezésében Jakucs Pállal egyetemben, gyantát gyüjtöttek az Észak-Erdéllyel visszacsatolt Radnai-havasokban. Tanári pályára készült, és egyértelmü volt számára, hogy az érettségi után a háborús sebeket éppen kiheverő, frissen induló felsőoktatásban a biológia-földrajz szakot választja.

Egyetemi professzorai közül a Kolozsvárról érkezett Soó Rezső gyakorolt rá maradandó hatást. Az oktatásba és kutatásba, a nyugat-európai növényföldrajzi szemlélet meghonosításába nagy energiát fektető Soó felismerte a lelkes diákban a tehetséget, és már egyetemistaként alkalmazta a tanszékén eleinte díjazatlan, később mint díjazott demonstrátort. A terepi munka, a gyűjtőutak és a herbárium rendezése során egyre több fajt ismert meg, ezzel megalapozva azt a hatalmas tudásanyagot, amelyről nagyon korán nevezetessé vált. Hankó Bélának, Sátori Józsefnek és Nagy Barnának köszönhetően a zoológia iránti érdeklődése is megmaradt, de végül Soó erős egyénisége döntött. Az 1950-es évek elején ő vonta be fiatal kollégáját az akkor kibontakozó természetvédelmi felmérő munkába is. Elkészítették az Észak-Alföld botanikai térképét, $1: 25$ 000-es léptékben. Számos, akkor az Alföldre nézve új növényfajt találtak (pl. Leucojum vernum, Euphorbia carpatica). Együtt dolgozott Jakucs Pállal, aki hamarosan a Magyar Természettudományi Múzeum Növénytárában kapott állást, de később profeszszorként visszatért Debrecenbe. Simon Tibor számára az országos ismertséget a Csaroda melletti tőzegmohaláp felfedezése hozta meg, ahol számos ritka (azóta még ritkább) reliktum fajt mutatott ki. A tőzegáfonya magyar alföldi felfedezése olyan nagy botanikai szenzáció volt, hogy Soó professzor a Tudományos Akadémián Simon Tibor eredményeit külön előadásban mutatta be. Még a fel- 
fedezés évében országos jelentőségű természetvédelmi területté nyilvánították a lápot. Megjelentek első publikációi, például az egyetemi Annalesben, melynek nyomdai előkészítésében a fiára büszke édesapja betűszedőként vett részt. 1952-ben kötött házasságot Wolcsánszky Erzsébettel, vagy, ahogy leginkább ismerik-ismerjük, Pötyikével, aki akkor a Debreceni Agrártudományi Egyetemen, a Növénytani Tanszéken oktatott, majd a gödöllői Agrártudományi Egyetem Növénytani Tanszékét, később az Egri Tanárképző Főiskola Növénytani Tanszékét vezette. Egyetemi tanársegéddé nevezték ki, majd 1952-1954 között aspiránsként dolgozott Soó mellett. Tibor a nála 9 évvel fiatalabb Juhász-Nagy Pál munkáját is irányította; együtt járták a Beregi-sík tájait, felmérve az ottani rétek cönológiai viszonyait. Ekkor alakult ki közöttük az az élethosszig tartó szoros barátság, amiből mind a ketten sokat profitáltak, de még többet leendő munkahelyük és annak kollektívája - de erről majd később.

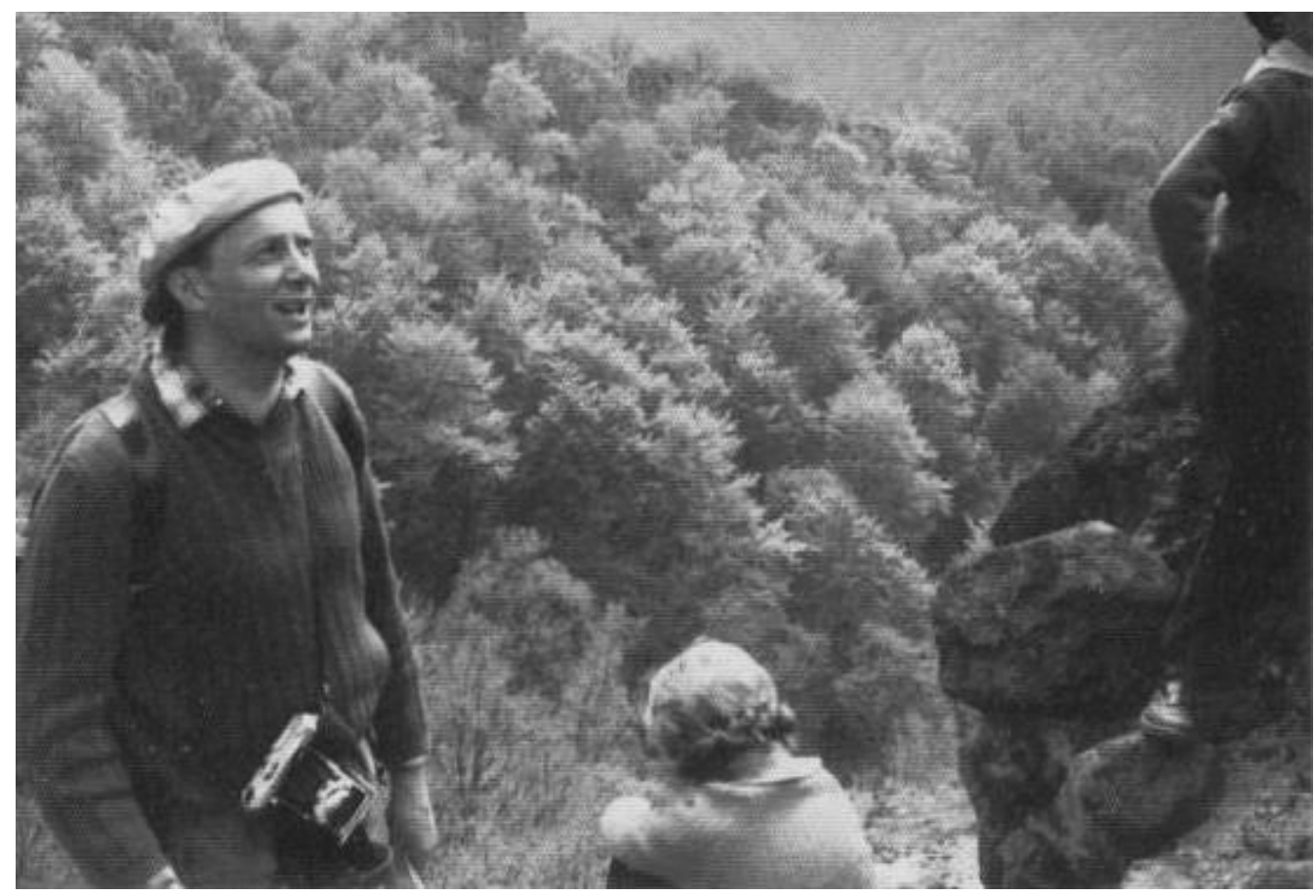

A füzéri Várhegy oldalában, 1960-ban. A hegyre először Juhász-Nagy Pállal másztak fel. Tibor később rendszeresen visszatért ide, a vulkáni kúp sziklanövényzetének megismerése az általa vezetett hallgatói terepgyakorlatoknak is elmaradhatatlan részévé vált. (A felvétel a Simon család archívumából származik.)

On the side of Füzér Castle Hill, in 1960. Tibor first climbed the hill with Pál Juhász-Nagy, his lifelong colleague and friend. Later he returned here regularly to explore the rock grassland vegetation of the volcanic cone. This site became an indispensable part of the student field trips he led. (The photograph comes from the Simon family archive.) 
Akkoriban nem volt egyszerü külföldre utazni, de neki megadatott, hogy 1954-ben Szatala Ödön lichenológussal eljutott Bulgáriába. Talán nem is kell hangsúlyozni, mekkora hatással volt rá, mint alföldi emberre az ottani magashegységi táj, a Rila és a Pirin sajátos növényvilága. Nem sokkal az után, hogy 1955ben megvédte kandidátusi disszertációját, főnöke és egyben mentora a budapesti Eötvös Loránd Tudományegyetemre került az akkori Növényrendszertani és Növényföldrajzi Tanszékre. Simon Tibornak nem volt sok választási lehetősége, úgy döntött, hogy Soó indítványára családostul ő is a fövárosba költözik. Ezt a lépését nem bánta meg, bár sajnálta, hogy ifjúságának kedvenc helyeit, a rokonságot és barátait már csak ritkábban látogathatta. Új munkahelye azonban lehetőséget adott számára, hogy az egész országot bejárja, komoly botanikai tapasztalatokat szerezve a Duna-Tisza közén és a Dunántúlon is. Rögtön kapcsolatba lépett a fővárosban dolgozó fiatal botanikusokkal, akik ebből a barátságból sokat nyertek. Karrierje gyorsan ívelt felfelé, már 35 évesen kinevezték egyetemi docenssé, majd 1966-ban a tanszékről kissé viharos körülmények között távozó Soó-t követte a vezetői pozícióban, amit 1996-ig, nyugdíjba vonulásáig meg is tartott - mindenki megelégedésére. Soó professzor egyik jó tulajdonsága volt, hogy tehetséges tanítványait mindenben támogatta, előrejutásukat segítette. Ennek ellentéteként viszont, ha úgy érezte, hogy valamelyik munkatársa vagy tanítványa valamilyen területen öt megközelíti vagy megelőzi, azokkal nagyon összekülönbözött. Ennek egyik első jele volt, amikor a Zólyomi Bálint akadémikus vezetésével működő növénytári kutatócsoport működését (melynek Fekete Gábor, Jakucs Pál és Pócs Tamás voltak tagjai) féltékenységgel figyelte, és megtiltotta tanszéke tagjainak a velük való együttmüködést. Simon Tibor barátságos és szeretetteljes egyéniségével ezt a problémát is áthidalta, és telefonon megbeszélt titkos szakmai találkozókat szervezett a csoport részére a Botanikus Kerttel szemközti, Illés utcai kis kocsmában.

Budapesten domborodott ki igazán Simon Tibor munkásságnak három fó vonala, a botanikai-cönológiai kutatómunkája, az oktatói-ismeretterjesztői tevékenysége és közéleti aktivitása, de nem külön-külön, hanem szerves egységben egymással. Mint terepi kutatót, elsősorban a hajtásos növények és a mohák érdekelték, számos fajt (pl. a Drosera, Vaccinium, Sphagnum nemzetségekből) ö talált meg először a magyar flórában, ill. ő mutatott ki teljesen váratlan lelőhelyekről. Sok faj felfedezése kapcsolható a bulgáriai és romániai útjaihoz is, melyek anyagát Vajda László, Vida Gábor és Pócs Tamás közreműködésével dolgozta fel. Ezek közül talán legnevezetesebb az Aubrietia croatica Páreng hegységi felfedezése, amely nemzetség és faj addig a Kárpátokban ismeretlen volt. Igazi szenvedélye a cönológia,

\footnotetext{
* Az eredeti cikkben Aubrietia nemzetségnévvel publikálták (Pócs és Simon 1957). A taxon jelenleg elfogadott neve Aubrieta columnae subsp. croatica (Schott, Nyman \& Kotschy) Mattf.
} 
azaz a növénytársulás-típusok felismerése, osztályozása és ökológiai viszonyainak a jellemzése volt. Kandidátusi disszertációjának a témájaként az Észak-Alföld növénytársulásait választotta, de sokat foglalkozott a Zemplén erdeivel, sziklagyepjeivel, és általában a lápok növényzetével is. Borhidi Attilával, Juhász-Nagy Pállal, Pócs Tamással és Vida Gáborral feldolgozták a Páreng hegység növénytársulásait. Egy hétre való elemózsiával és teljes tábori felszereléssel a tekintélyes méretű hátizsákban, havasi pásztortanyákon a tủz mellett alva és hatalmas mennyiségü növényanyagot lehozva, itt váltak nyilvánvalóvá Tibor nagy munkabírással és szaktudással párosult kiemelkedő terepkutatói képességei. Több új társulástípust közölt, nemcsak hazánkból és a környező országokból, hanem még Kínából is. A kezdeti, inkább leíró jellegü kutatásokat később oknyomozó, ökológiai központú vizsgálatok váltották fel. Figyelme a Szigetköz és a Duna-Tisza köze növényzetét befolyásoló környezeti viszonyok vizsgálata felé fordult. Bekapcsolódott az 1960-as évektől népszerủ anyagforgalmi és produkciós vizsgálatokba, elsősorban homokpusztai gyepekben. Lényeges szerepe volt a hazai moha-ökológiai kutatások beindításában, illetve a szigetközi monitoring rendszer kialakításában és fenntartásában. Sokrétű munkásságát eme rövid összesítésnél sokkal jobban illusztrálja tudományos publikációinak a cikkünk végén megadott listája.

Az ELTE-n töltött első éveket a botanikus kert rendbehozatalával töltötte, és bekapcsolódott a talajtan oktatásába, melynek anyagát már Debrecenben kidolgozta Juhász-Nagy Pállal együttmüködve. Legkedveltebb tárgyai a növényökológia és a növényrendszertan voltak, de ezek mellett számos speciális kollégiumot is szervezett, például a növénycönológia témakörében. Fontosnak tartotta, hogy az egyetemi hallgatók ne csak elméleti és laboratóriumi képzésben részesüljenek, hanem terepi ismeretekhez is hozzájussanak. Ennek köszönhetően sokaknak jelentettek maradandó élményt az általa szervezett és vezetett hazai terepgyakorlatok, majd a szovjetunióbeli csereutak.

Ezek létrehozása remek példa Simon Tibor kiváló helyzetfelismerésére. Történetesen 1970-ben a Minisztériumból kapott váratlanul egy telefonhívást, hogy tudna-e segíteni egy hazánkba látogató 20 fős üzbég csoport 3 hetes programjának megszervezésében. Ö rövid gondolkodás után elvállata a nem kevés nyári elfoglaltságot jelentő feladatot, de kialkudta, hogy a következő évben egy magyar csoport mehessen el Üzbegisztánba. Az utazásra 1971-ben került sor, ahol aztán megegyeztek a Taskenti Egyetemmel, hogy ezentúl minden évben csereutakat szerveznek. A viszszaút tervezésekor Simon Tibor felvetette, hogy ne a legrövidebb, Kijeven át vezető utat válasszák, hanem kerüljenek Tbiliszi felé. Az ilyesmihez kellett egy adag vagányság, mivel az akkori Szovjetunióban nem lehetett „csak úgy” bolyongani, de erre ő így reagált: „Mi történhet velünk? Legfeljebb hazaküldenek, de hát amúgy is oda igyekszünk." A grúzok persze azt gondolták, hogy a magyar csoport felbukkanása csakis a legfelsőbb hatóság tudtával történhetett. Ezért, no meg a grúz-magyar 
barátság fehér asztal melletti felelevenítése közben meg is született az elhatározás, hogy a következő évtől a Tbiliszi Egyetemmel is rendszeres csere-terepgyakorlatokat szerveznek minden nyáron. E két egzotikus, távoli ország nehezen elérhető tájainak természeti viszonyait és embereit ezután több száz biológus és biológiatanár szakos hallgató ismerhette meg egészen az 1980-as évek legvégéig.

Oktatás nem megy jegyzetek és tankönyvek nélkül, és Simon Tibor a tanszéken oktatott tárgyak majd mindegyikéhez készített írásos anyagot. A jónéhány kiadást megért Növénytan 2, majd Növényföldrajz, társulástan és ökológia címü felsőoktatási tankönyvek jelentős fejezeteit írta. Az oktatást és a kutatást egyaránt elősegítette azzal, hogy a nagy elődök (elsősorban Jávorka Sándor) munkáit átdolgozva és felfrissítve elkészítette a magyar edényes flóra határozókönyvét, amely 2008-ig több kiadásban is megjelent. Ez a munka nem hiányozhatott a hazánkban dolgozó botanikus-növényökológus kutatók és tanárok könyvespolcáról, és a leginkább idézett (vagy sokszor nem is idézett, „csak” használt) referencia-művé vált a szakmában. E téren munkássága abból a szempontból is unikális, hogy az edényes flórát tárgyaló kötet párját adó - a virágtalan növények további csoportjait felölelö - vaskos határozókönyv szerkesztése is az ő nevéhez füződik. Talán még ennél is fontosabb, de mindenképpen ismertebb munkája a Csapody Vera akvarelljeivel illusztrált „Kis növényhatározó”. A szélesebb olvasóközönségnek és a középiskolásoknak szánt könyv 1966 és 1996 között 21 kiadást ért meg! És ezzel még nem volt vége, hiszen átdolgozott formában, Seregélyes Tibor fotóival és Csomós Ágnes rajzaival kiegészítve „Növényismeret” címen további tíz kiadásban jelent meg, 1998-ban elnyerve a frankfurti nemzetközi könyvkiállítás nívódíját is. De nem feledkezhetünk meg a Juhász-Nagy Pállal közösen, 1971ben elindított Abstracta Botanica nevü folyóiratról sem. Ez kezdetben a tanszéken készült disszertációk szerzőinek biztosított megjelenési lehetőséget, majd nemzetközileg is jegyzett folyóirattá vált. Húsz éve, külföldi lapokkal való egyesítés után Community Ecology néven jelenik meg, és a siker egyértelmü jelzőjeként a Springer vette át a kiadással járó feladatokat (no meg a bevételek egy részét is).

Közéleti tevékenysége 1971-től vált egyre inkább érezhetővé, amikor kinevezték az ELTE TTK dékánhelyettesévé. Ebben a funkciójában járult hozzá a kar szerkezeti és szervezeti felépítésének átalakításához, több tanszék megújításához, sőt újak alapításához. Ezek vezetésére olyan kiváló szakembereket hívtak, mint Csányi Vilmos, Gergely János, Szabó I. Mihály és Vida Gábor, akik később valamennyien az MTA rendes tagjai lettek.

Vida Gábort például személyesen kereste fel az akkor Vácrátóthoz tartozó, de a budai Herman Ottó úti telep egyik épületében mủködő mikroevolúciós csoportnál, és rábeszélte, hogy vállalja el a Genetika Tanszék vezetését. Elmondta neki, hogy a páfrány-evolúciós kísérleteire nem lesz annyi ideje, mint a kutatóintézetben, de cse- 
rébe egy szélesre táruló tudástérben dolgozhat majd az egyetemen. Jóslata mindkét tekintetben beigazolódott, de Vida Gábor soha nem bánta meg a váltást.

Dékánhelyettesként olyan feladatokat is el kellett látnia, amelyek - szerencsére ma már nem terhelik a hasonló funkciót betöltő oktatókat. Neki kellett engedélyezni (vagy nem engedélyezni) az egyetemi hallgatók útlevélkérelmeit is, különösképpen a nyugati országokba szóló kérelmeket. Egyikünk (PJ) egy évfolyamtársával fejébe vette, hogy 1973 nyarán Angliába utazik, szerzett is magánjellegü meghívólevelet, és ennek birtokában kérte az egyetemet, hogy támogassa őket a „látogató útlevél" kiváltásában. Ehhez Simon Tibor hozzá is járult, és ahogy évtizedekkel később elmesélte, kapott is „felülről” szemrehányást bőven: „vállalja-e a felelősséget, ha a fiúk majd nem jönnek haza?" De erre csak mosolyogva reagált, hiszen akkor már régen itthon volt mindkettő.

Az átszervezés során, a megváltozott feladatokat is tükrözve, munkahelyének új neve Növényrendszertani és Ökológiai Tanszék lett. Időközben a „Vegetationsuntersuchungen im Zempléner Gebirge" c. munkájával megszerezte a biológiai tudományok doktora címet, és 1973-ban kinevezték egyetemi tanárrá. Tevékeny résztvevője volt különféle hazai és nemzetközi testületeknek, elnöke volt az MTA Botanikai Bizottságának és a Biológus Habilitációs Bizottságnak, a Magyar Biológiai Társaságnak (MBT), ill. az MBT Természetvédelmi Szakosztályának. 1966tól 1993-ig a Botanikai Közlemények folyóirat szerkesztője. Jelölték MTA tagságra is, de megválasztása, sajnos, a hírek szerint nem teljesen korrekt módon, elmaradt. 1978-ban megalapította az MTA-ELTE Ökológiai Modellező Tanszéki Kutatócsoportot, ami kissé megváltozott formában mind a mai napig működik. A tanszéken futó Elméleti Biológiai és Ökológiai Doktori Programnak is ő volt az első vezetője. A tanszék munkáját számos kutatási pályázat elnyerésével biztosította. 1981-ben alapította meg a Kiskunsági Nemzeti Parkhoz tartozó bugaci ősborókásban a Juniperus kutatóházat. Ez a faépület föhadiszállásul szolgált a tanszéki és vendégkutatók számára mindaddig, amíg 2012-ben egy 1100 hektárra kiterjedő, nagy tüz martalékává nem vált.

Simon Tibornak a természetvédelem és az oktatás területén végzett munkásságát számos kitüntetéssel is elismerték. 1985-ben kapta meg a Pro Natura díjat és a Magyar Biológiai Társaság (MBT) Herman Ottó díját. 1991-ben az Eötvös Loránd Tudományegyetem Pro Universitate Emlékérmét vehette át. 1994-ben ismét az MBT Gelei József-emlékéremmel tüntette ki, majd ugyanebben az évben Kosáry Domokos, az MTA elnöke adta át neki az Eötvös József Koszorút. 1997ben elnyerte a Pázmány Péter Felsőoktatási Díjat, 2002-ben a Tuzson János emlékérmet, 2003-ban pedig a Magyar Köztársasági Érdemrend lovagkeresztjét vehette át. A tudományos ismeretterjesztésért 2009-ben Szily Kálmán emlékéremben részesült. 
1996-os nyugdíjazása után is aktív tagja maradt a Tanszéknek, így minden tekintetben rászolgált a Professor Emeritus címre (1997). Rendszeresen részt vett a doktori iskola munkájában, ahol akkoriban vagy a doktori szigorlati bizottság elnöki tisztét látta el, vagy a védési bizottság elnökeként volt nélkülözhetetlen szerepe a doktori eljárások lefolytatásában. Időközben a más intézményekhez kötődő feladatait, bizottsági- és testületi tagságokat bölcsen átgondolt fokozatossággal lemondta. A hosszú pályafutása során összegyüjtött könyvtára értékes szakkönyveiből rendszeresen ajándékozott köteteket az adott témakörrel foglalkozó fiatal botanikusoknak, 2018-ban az 1200 kötetet számlátó szakkönyvtárát az ELTE Füvészkert Könyvtárának, az ezret jóval meghaladó darabszámú különlenyomat gyüjteményét pedig a szombathelyi Berzsenyi Dániel Főiskola Könyvtárának adományozta. Ugyanakkor az évről évre esedékes, május-júniusra időzített „tanszéki kirándulásoknak” továbbra is aktív szervezője és résztvevője volt (Budai-hegység, Börzsöny, Csévharaszt, Vértes). Mindnyájunkat ámulatba ejtett, hogy 85 éves korában is milyen könnyedén és magabiztosan mozgott a hegyoldalakon, ha pedig egy-egy jellegzetes növénytársulás tipikus állományához érkeztünk, elmondta mindazt, amit a hely ökológiai viszonyairól és jellemző fajkészletéről tudni érdemes. Idős korában is megőrzött erőnlétét jól példázza Isépy István alábbi visszaemlékezése:

2005 táján történhetett, hogy a Füvészkertben az egyik délelőtt megkérdezte tőlem: elmennék-e vele egy kis kirándulásra, mert be akarja járni azt az utat, ahová majd a Tanszék munkatársait viszi egy nyár eleji kirándulásra. „Szép, kényelmes völgyi út, országos kék", a Nagy-Szénás oldalában Piliscsabától Nagykovácsiba. Örömmel mondtam igent. A valóban kellemes séta során, ahol a kőtörmelékes lejtő legmeredekebben szakadt a völgyalj felé, magálltunk. Simon Tibor megszólalt ,úgy emlékszem, Zólyomi a Budai-hegységről 1958-ban írt munkájában említi, hogy ezeken a gerinceken is nő a Carex alba". Mire kimondta, már félúton járt. A tetőn értem őt utol, s örömmel szólt: „Nézz csak a lábad alá! Látod, itt van!”. Ezt a mutatványt Nagykovácsiig még háromszor megismételtük.

Amiért ritkán jár külön kitüntetés, mégis a legfontosabb, az a személyiség. Tibor Bátyánk egészen különleges derűvel kezelte az életet, modora közvetlen volt, segítségére volt mindenkinek. Teljességgel hiányzott belöle a hiúság vagy szakmai féltékenység. Ha fiatal kollégái körében olyan új kutatási témák merültek fel, amiről neki nem volt tapasztalata, soha nem volt rest érdeklődni, és tőlük tanulni. A fordított helyzet azonban még sokkal gyakrabban előfordult. Ajtaja nem csak a kollégák, de minden érdeklődő hallgató előtt is nyitva állt, akik éltek is a lehetőséggel, hogy közvetlenül a Professzorhoz fordulhatnak, akár egy öszszetettebb szakmai kérdés megoldása, akár csak egyetlen nehezen felismerhető növény meghatározása volt a cél. Nem meglepő, hogy haragosai sem akadtak. 


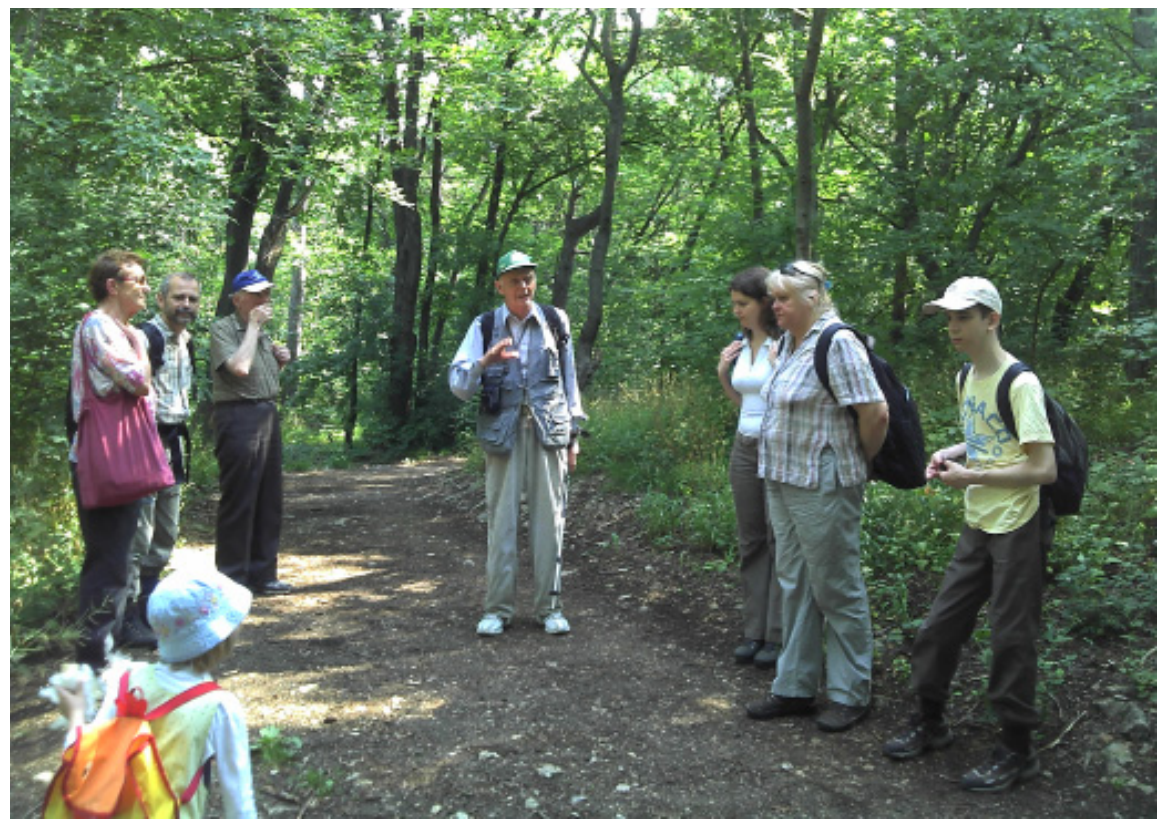

Tanszéki kiránduláson a Hármashatár-hegyen, 2011. június 5-én (Csontos P. felvétele). Leading a fieldtrip to department staff and their families on the Hármashatár Hill (Budapest) on 5 June 2011. (photo by P. Csontos).

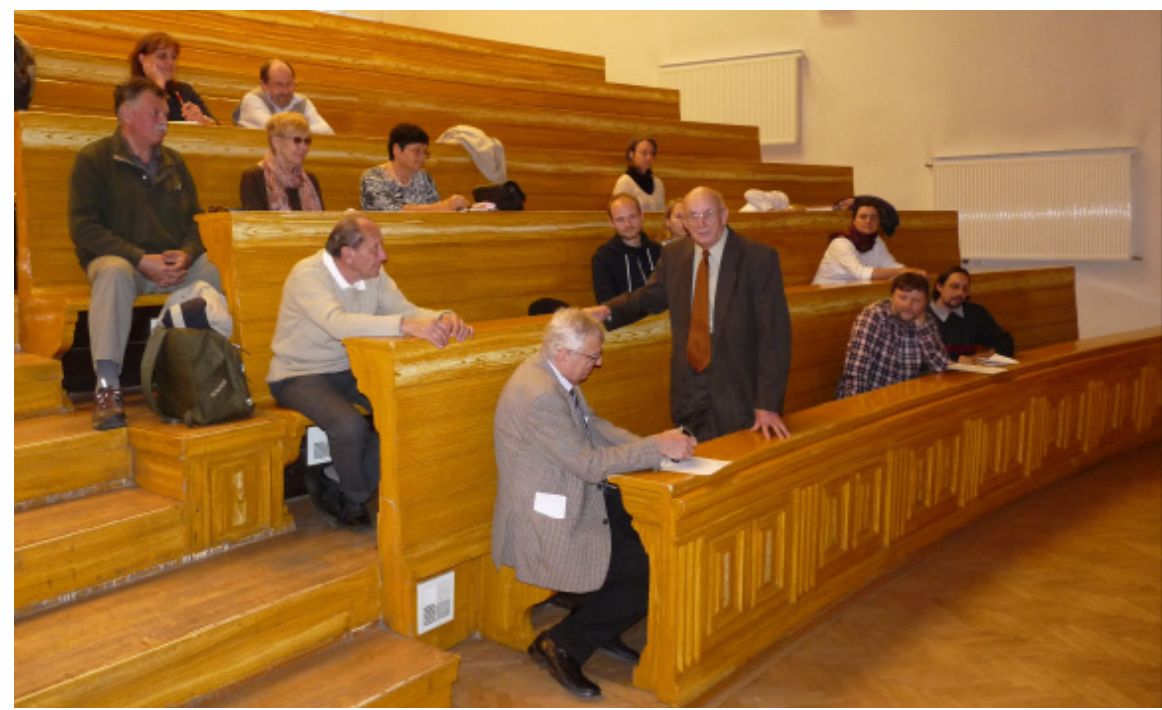

Simon Tibor hozzászólása a Botanikai Szakosztályban Csapody Vera születésének 125. évfordulója alkalmából rendezett ülésen, az ELTE Múzeum krt. 4/A sz. alatti Gombocz Zoltán termében, 2015. október 26-án (Csontos P. felvétele).

Tibor Simon giving a comment from the audience at the meeting of the Botanical Section of the Hungarian Biological Society organized on the occasion of the 125th anniversary of the birth of Vera Csapody in the Zoltán Gombocz lecture hall of the ELTE (Múzeum krt. 4/A, Budapest) on 26 October 2015. (photo by P. Csontos) 
Irigyei talán igen, mert a feladatokat Juhász-Nagy Pállal megosztva páratlanul jó közösséget alakított ki a munkahelyén. Nekik köszönhetjük, hogy a ma már Növényrendszertani, Ökológiai és Elméleti Biológiainak nevezett tanszéken a nagy témabeli sokféleség ellenére sem tapasztalható az a belső feszültség, ami másutt elég gyakran előfordul. Bár hosszú ideig volt vezető beosztásban, diktatórikus stílusnak még a nyomát sem lehetett felfedezni benne. Nem utasított senkit, nem parancsolt a beosztottjainak. Sokan emlékezhetünk arra, hogy amikor egy-egy tárgy oktatásával meg akart bízni valakit, akkor csak a vállára tette a kezét, $s$ az illető már tudta is, hogy ezentúl kevéssel több órája lesz. Nagy anekdota-mesélő volt, kiváló humorérzékkel rendelkezett - és jól viselte a finom csipkelődést is. Jobban semmi sem bizonyítja ezt, $s$ egyben a hallgatók-kollégák szeretetét, mint a közismert népdal legalább ötven éve létező parafrázisa - amit itt most teljes egészében be is mutatunk.

„Megismerni a Simont fürge járásáról,
tüzött-füzött bakancsáról, növényásójáról.
Hej, élet, élet, füvészélet, ez aztán az élet,
Ha megunom magamat, Simonnal cserélek.
Erdőbe ment a Simon, csak a feje látszik,
Rásütött a holdvilág, messziről világít.
Hej, élet, élet, füvészélet, ez aztán az élet,
Ha megunom magamat, Simonnal cserélek.
Ez itten a Luzula, a savanyút jelzi,
Simon orra a kocsmát messziről megérzi.
Hej, élet, élet, füvészélet, ez aztán az élet,
Ha megunom magamat, Simonnal cserélek.

Huperzia selago, kérem ki ne ássa, Fontos reliktumnövény, elég ha csak lássa! Hej, élet, élet, füvészélet, ez aztán az élet, Ha megunom magamat, Simonnal cserélek."

Kirándulásokon, rendezvényeken maga is csatlakozott a kórushoz - csak annyit változtatott a refrénen, hogy „magammal cserélek”.

Szerencsésnek mondhatjuk magunkat, hogy Simon Tibort hosszú éveken át ismerhettük, és közeli barátságba is kerülhettünk vele. Szerencse az is, hogy ezt még nagyon sokan elmondhatják magukról. Emlékét, szellemi örökségét megőrizzük. 


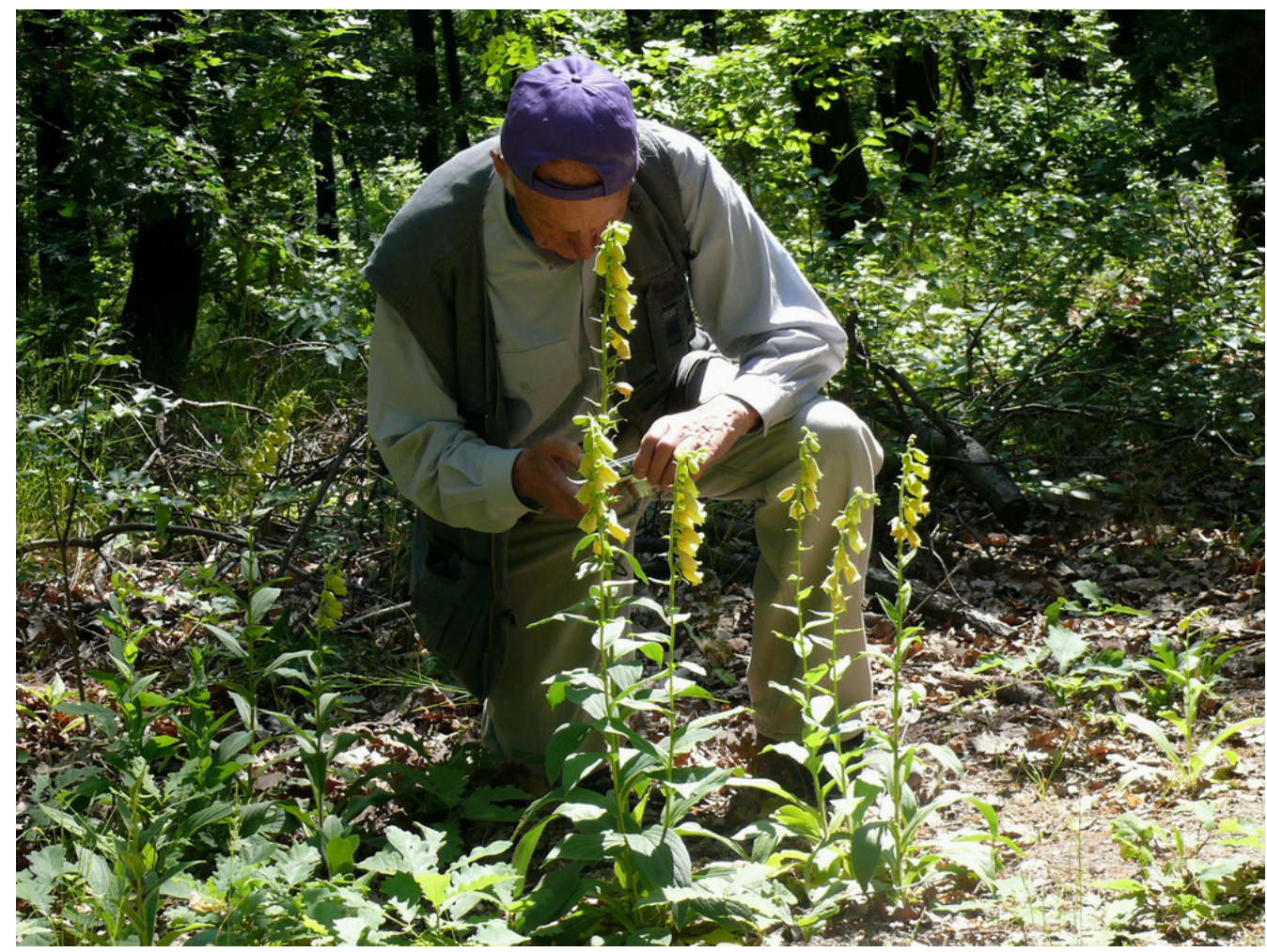

A Nagy-Kevély tölgyerdejében, 2009. május 23. (Podani J. felvétele). In the oak woodland of Nagy-Kevély on 23 May 2009 (photo by J. Podani).

\section{Köszönetnyilvánítás}

Szerzők köszönettel tartoznak Isépy Istvánnak a kézirat lektorálásáért, egyes részek pontosításáért, kiegészítéséért.

\section{Simon Tibor publikációinak jegyzéke ${ }^{* *}$}

Simon T. 1949: Két új Euphorbia hibrid és egy új Euphorbia faj Magyarországon. Borbásia 9(6-10): 92-95.

Simon T. 1950: Montán elemek az Északi-Alföld flórájában és növénytakarójában. Annales Biologicae Universitatis Debreceniensis 1: 146-174. + 4 tábla

Simon T. 1951: Évelő pázsitfüvek összes nitrogén-, nyerscellulóze és hamutartalmának vizsgálata. Annales Biologicae Universitatis Hungaricae 1: 291-302.

Simon T. 1951: Montán elemek az Északi-Alföld flórájában és növénytakarójában II. Annales Biologicae Universitatis Hungaricae 1: 303-310.

\footnotetext{
** A jegyzék nem tartalmazza Simon Tibor több mint 30 könyvismertetőjét, melyeket természetvédelmi és botanikai tárgyú ismeretterjesztő- és szakkönyvekről írt.
} 
Simon T. 1951: Növényföldrajzi kutatási módszerek a Szovjetunióban. In: Soó R., Zólyomi B. (szerk.) Növényföldrajzi térképezési tanfolyam jegyzete. Kézirat, Vácrátót, pp. 112-121.

Simon T. 1952: Montán elemek az Északi-Alföld flórájában és növénytakarójában III. Annales Biologicae Universitatis Hungaricae 2: 279-286.

Simon T. 1953: Torfmoore im Norden des Ungarischen Tieflandes. Acta Biologica Academiae Scientiarum Hungaricae 4(1-2): 249-252.

Simon T., Kenyeres L. 1953: A Nyírestó és a Bábtava. Természet és Technika 112(2): 90-93.

Simon T. 1954: A modern geobotanika néhány problémája a Szovjetunióban. Botanikai Közlemények 45(3-4): 175-182.

Simon T. 1954: Az Északi-Alföld erdei. Erdőtípusok, termőhelyi osztályok és fahozam összefüggései fitocönológiai alapon. Kandidátusi értekezés, kézirat, Debrecen, 143 pp.

Simon T. 1955: Az erdő fogalmáról és osztályozásának elvéről. Acta Universitatis Debreceniensis 2: 211-218.

Simon T. 1956: Bátorliget növényzetéről. In: Szalontai B. (szerk.) Nyírbátor története. A Nyírbátori Báthori István Múzeum Füzetei, Nyírbátor, pp. 56-64.

Simon T., S. Wolcsánszky E. 1956: Gazdasági növénytan. Mezőgazdasági technikumi tankönyv. Mezőgazdasági Kiadó, Budapest, 303 pp.

Pócs T., Borhidi A., Juhász-Nagy P., Simon T., Skoflek I., Vida G. 1957: Contributions á la flora des Carpathes orientaux et méridionaux. Annales Historico-Naturales Musei Nationalis Hungarici, Series Nova 8: 205-217.

Pócs T., Simon T. 1957: Aubrietia croatica Sch., Nym. et Ky. neu für die Flora der Karpaten und Rumäniens. Acta Botanica Academiae Scientiarum Hungaricae 3(1-2): 31-36.

Simon T. 1957: A Sátorhegység növényvilága. Élővilág 2(3): 38-45.

Simon T. 1957: Die Wälder des Nördlichen Alföld. Die Vegetation Ungarischer Landschaften 1. Akadémiai Kiadó, Budapest, 172 pp.

Simon T. 1958: Februári virágok. Természettudományi Közlöny 89(2): 59-61.

Simon T. 1958: Ébred az erdő alja. Természettudományi Közlöny 89(4): 155-157.

Simon T. 1958: Über die alpinen Pflanzengesellschaften des Pirin-Gebirges. Acta Botanica Academiae Scientiarum Hungaricae 4: 159-189.

Simon T. 1959: Bolgár havasok virágai. Élővilág 4(3): 3-11.

Simon T. 1959: Virító orchideák. Természettudományi Közlöny 90(3): 120-121.

Simon T., Vajda, L. 1959: Beiträge zur Moosflora Bulgariens. Annales Universitatis Scientiarum Budapestinensis de Rolando Eötvös Nominatae, Sectio Biologica 2: 259-272.

Simon T. 1960: Botanikus szemmel a Duna-deltában. Természettudományi Közlöny 91(4): 170-172.

Simon T. 1960: Contributions á la connaissance de la végétation du Delta du Danube. Annales Universitatis Scientiarum Budapestinensis de Rolando Eötvös Nominatae, Sectio Biologica 3: 307-333.

Simon T. 1960: Die Vegetation der Moore in den Naturschutzgebieten des Nördlichen Alföld. Acta Botanica Academiae Scientiarum Hungaricae 6(1-2): 107-137.

Simon T. 1960: Látogatás a konstancai Tengerkutató Állomáson. Búvár 5(1): 50-51.

Simon T. (szerk.) 1960: Növényrendszertani terepgyakorlatok. Egyetemi jegyzet, ELTE, Budapest.

Simon T. 1960: Viktória virágzás a Botanikus Kertben. Búvár 5(3): 138-141.

Soó R., Simon T. 1960: Bemerkungen über südosteuropäische Fraxinus- und Dianthus-Arten. Acta Botanica Academiae Scientiarum Hungaricae 6(1-2): 143-153.

Simon T. 1961: Biológiai terepgyakorlaton a Német Demokratikus Köztársaságban. Felsőoktatási Szemle 10(6): 358-361.

Simon T. 1961: Geobotanikai tanulmányúton a Távol-Keleten. Botanikai Közlemények 49(1-2): 19-26. 
Csapody I., Horánszky A., Simon T., Pócs T., Szodfridt I., Tallós P. 1962: Lágyszárú növényeink ökológiai viszonyai. In: Majer A. (szerk.) Erdő- és termőhelytipológiai útmutató. Országos Erdészeti Főigazgatóság, Budapest, pp. 165-175.

Simon T. 1962: A Kisalföld természetes növénytakarója. Földrajzi Közlemények 2: 183-193.

Simon T. 1962: Contributions to the vegetation of delta of the Danube. Acta Biologica Academiae Scientiarum Hungaricae 12(Suppl. 4): 18.

Simon T. 1962: Botanikai kirándulás a dél-szibériai tajgába (Részlet a szerző távol-keleti útinaplójából). Élővilág 7(2): 3-9.

Simon T. 1962: Kínai botanikus kertekben. Búvár 7(2): 117-122.

Simon T. 1962: Vergleichende Torfmoorstudien in den Karpaten. Acta Botanica Academiae Scientiarum Hungaricae 8(1-2): 187-203.

Csapody I., Horánszky A., Simon T., Pócs T., Szodfridt I., Tallós P. 1963: Die ökologischen Artengruppen der Wäldern Ungarns. Acta Agronomica Academiae Scientiarum Hungaricae 12(12): 209-232.

Simon T., Dihoru G. 1963: Die Tamarix-Auen am Flusse Buzău in Rumänien. Annales Universitatis Scientiarum de Rolando Eötvös Nominatae, Sectio Biologica 6: 159-173.

Simon T., Juhász-Nagy P. 1963: Talajtan - mint a növényökológia alapja. Egyetemi jegyzet. Tankönyvkiadó, Budapest, 144 pp.

Simon T. 1964: A Bihar-hegység növényvilága. Természettudományi Közlöny 95(4): 158-161.

Simon T. 1964: Contributions to the knowledge of some plant communities of China. Advancing Frontiers of Plant Sciences (New Delhi) 8: 135-149.

Simon T. 1964: Entdeckung und Zönologie der Festuca dalmatica (Hack.) Richt. in Ungarn un ihr statistischer Vergleich mit ssp. pseudodalmatica (Kraj.) Soó. Annales Universitatis Scientiarum de Rolando Eötvös Nominatae, Sectio Biologica 7: 143-156.

Simon T., Borsos O. 1964: Ad honorem academici professoris Rezső Soó sexagesimi. A collaboratoribus Horti Botanici Universitatis Budapestinensis composita. Állami Nyomda, Budapest, $21 \mathrm{pp}$.

Simon T., Kovács-Láng E. 1964: Relationships of plant communities and soil types on the nature conservation area of Csévharaszt. Acta Biologica Academiae Scientiarum Hungaricae 15(Suppl. 6): 25-26.

Simon T. 1965: A legfejlettebb növényeink: a zárvatermők. Természettudományi Közlöny 96(12): 564-569.

Simon T. 1965: Érdekes virágzás-fenológiai jelenségek az 1964. év végén. Természettudományi Közlöny 96(1): 44.

Simon T. 1965: Über die Seslerietum rigidae-Assoziationen in Siebenbürgen. Acta Botanica Academiae Scientiarum Hungaricae 11(1-2): 221-234.

Simon T. 1966: A csarodai és a kállósemjéni természetvédelmi területek növényvilága. SzabolcsSzatmári Szemle 1(2): 21-29.

Simon T. 1966: Beiträge zur Kenntnis der Vegetation des Bihar (Bihor) Gebirges. Annales Universitatis Scientiarum de Rolando Eötvös Nominatae, Sectio Biologica 8: 253-273.

Simon T., Csapody V. 1966: Kis növényhatározó. Tankönyvkiadó, Budapest, 179 pp. (A későbbiekben összesen 21 kiadásban.)

Simon T., Fülöp A. 1966: Die periodische Änderungen des pH-Wertes und des Humusgehaltes der Bestände von Festucetum vaginatae danubiale an der Insel Szentendre. A pH-érték és humusztartalom periodikus változása Festucetum vaginatae danubiale állományokban a Szentendrei-szigeten. Botanikai Közlemények 53(1): 35-41. 
Simon T., Vida G. 1966: Neue Angaben zur Verbreitung der Dryopteris assimilis S. Walker in Europa. Annales Universitatis Scientiarum de Rolando Eötvös Nominatae, Sectio Biologica 8: $275-284$.

Horánszky A., Simon T. 1967: Májusi virágok. Természettudományi Közlöny 98(11): 216-217. (Szerzőnevek feltüntetése nélkül.)

Simon T. 1967: Természetes növényzet. Dunamenti-síkság; Természetes növénytakaró. DunaTisza közi Hátság; Természetes növényzet. Drávamenti-síkság. In: Marosi S., Szilárd J. (szerk.) A Dunai Alföld. Magyarország tájföldrajza 1. Akadémiai Kiadó, Budapest, pp. 204207, 233-237, 305-306, +7 élőhelyfotó mellékletben.

Simon T., Mándy Gy. (szerk.) 1967: A komló - Humulus lupulus L. Magyarország Kultúrflórája VII/13. Akadémiai Kiadó, Budapest, 110 pp.

Simon T. 1967: A komló neve. A komló rendszertani helye. A komló külső alaktana. A komló károsítói c) Gyomnövények. A komló fajtarendszertana. In: Simon T., Mándy Gy. (szerk.) A komló - Humulus lupulus L. Magyarország Kultúrflórája VII/13. Akadémiai Kiadó, Budapest, pp. 7, 7-8, 17, 70-71, 92-94.

Simon T., Szőcs Z. 1967: Mnium hornum L. a Vértes-hegységben. Botanikai Közlemények 54(3): 147-148.

Simon T. 1968: A komló és a sör. Természet Világa 99(7): 324-325.

Simon T. 1968: Bevezetés a növényrendszertani részhez. Harasztok. Nyitvatermők. Zárvatermők: kétszikűek. A növényvilág kialakulása. In: Hortobágyi T. (szerk.) Növénytan 2. Tankönyvkiadó, Budapest, pp. 23-36, 212-238, 239-264, 265-423, 469-488.

Simon T. 1968: Die Torfmoor-Gesellschaften Ungarns. Acta Universitatis Debreceniensis de Ludovico Kossuth Nominatae, Series Geographica Geologica et Meteorologica 7(14): 201-206.

Simon T. 1968: Die Verbreitung der Heracleum sphondylium Unterarten in der ungarischen und karpatischen Flora. Annales Universitatis Scientiarum de Rolando Eötvös Nominatae, Sectio Biologica 9-10: 333-339.

Simon T. 1968: Szovjet-magyar botanika a Nagy Október emlékére. (Előszó a Szakosztály ünnepi ülésén, 1967. nov. 14-én elhangzott előadásokhoz.) Botanikai Közlemények 55(1): 1.

Simon T., Kovács-Láng E. 1968: A humuszprodukció frakcionált vizsgálata homoki pionír növénytársulás talajában. In: 8. Biológiai Vándorgyülés előadásainak ismertetése. Akadémiai Nyomda, Budapest, p. 12.

Simon T., Kovács-Láng E. 1968: Fractional analysis of humus production in the soil of pioneer sand plant community. Acta Biologica Scientiarum Hungaricae 19(4): 529.

Simon T., Tölgyesi Gy. 1968: Különböző termőhelyü Potentilla arenaria Borkh. populációk és talajaik makro- és mikroelem tartalmának összehasonlító vizsgálata. Comparative investigations on the macro- and microelement content of Potentilla arenaria Borkh. populations and their soils on different sites. Botanikai Közlemények 55(4): 267-272.

Simon T. 1969: Előszó. Magyarország természetes növénytakarója. Duna-Tisza közi hátság, Dunavölgyi tanulmányút. Hazánk fontosabb növénytársulásainak rendszeres áttekintése. Szlovákiai tanulmányút. In: Simon T. (szerk.) Növényrendszertani terepgyakorlatok. Egyetemi jegyzet, 2. bővített kiadás. Tankönyvkiadó, Budapest, pp. 5, 7-14, 20-38, 97-111, 115-137.

Simon T. 1969: Taxonomy of Hungarian cultivated hops. Acta Agronomica Academiae Scientiarum Hungaricae 18(3-4): 445-449.

Simon T. 1969: Természetes növényzet. In: Marosi S., Szilárd J. (szerk.) A tiszai Alföld. Magyarország tájföldrajza 2. Akadémiai Kiadó, Budapest, pp. 55-60 (Felső-Tiszavidék), 124-131 (KözépTiszavidék; Zólyomi Bálinttal közösen), 163-164 (Alsó-Tiszavidék), 241-246 (Nyírség), 294-296 (Körösvidék). +8 saját fénykép élőhelyekről.

Simon T. 1970: A gombák (Mycophyta) rendszere. A Növényrendszertani és Növényföldrajzi Tanszék tankönyvkiegészítő jegyzete. Kézirat. 
Simon T. 1970: Bryocönológiai és ökológiai adatok a Zempléni-hegységből. Botanikai Közlemények 57(1): 31-43.

Simon T. 1970: Tözegmohás növénytársulások új előfordulása a Tátika-Kovácsi hegycsoportban. Elözetes közlemény. Botanikai Közlemények 57(3): 200.

Simon T., Jurassa M. G. 1970: Classification of phytocenological samples by the aid of a computer. Annales Universitatis Scientiarum de Rolando Eötvös Nominatae, Sectio Biologica 12: 213-225.

Simon T., Vida G., Juhász-Nagy P. 1970: Report of the Hungarian CT working group. Bulletin Státny ustav památkové a ochrany prírody 2: 34-39.

Járai-Komlódi M., Simon T. 1971: Palynological studies on swamps of the Zemplén Mountains. Annales Universitatis Scientiarum de Rolando Eötvös Nominatae, Sectio Biologica 13: 103-113.

Priszter Sz., Simon T. 1971: 200 éve alakult meg a Tudományegyetem Növénytani Tanszéke és Botanikus Kertje. Botanikai Közlemények 58(1): 58.

Simon T. 1971: A csévharaszti természetvédelmi és IBP mintaterület. Állattani Közlemények 58(14): 105-111.

Simon T. 1971: A Duna-Tisza közi gyepek produkciójának kutatása. A Nemzetközi Biológiai Program csévharaszti mintaterülete. Búvár 26(3): 139-144.

Simon T. 1971: Mohagazdag szilikátszikla-gyepek a Zempléni-hegységben. Botanikai Közlemények 58(1): 33-45.

Simon T., Batanouny K. H. 1971: Qualitative and quantitative studies of the root system of Festucetum vaginatae. Annales Universitatis Scientiarum de Rolando Eötvös Nominatae, Sectio Biologica 13: 155-171.

Simon T., Juhász-Nagy P. 1972: Talajtan - mint a növényökológia alapja. Egyetemi jegyzet. Tankönyvkiadó, Budapest, 122 pp.

Simon T. 1972: A botanikus Fazekas Mihály nyomdokain. In: Nógrádi M. (szerk.) A Debreceni Fazekas Mihály Gimnázium (volt főreáliskola) Értesítője az 1972-73-as centenáriumi tanévről. Tankönyvkiadó, Budapest, pp. 175-177.

Simon T. 1972: Citoökológiai vizsgálatok cönológiai - ökológiai egységeken. Az MTA Biológiai Tudományok Osztályának Közleményei 15(1-2): 109-135.

Simon T. 1972: Die Pflanzengesellschaften der Felsenvegetation im Zempléner-Gebirge. (Math.stat. Bearbeitung mit Computertechnik). Annales Universitatis Scientiarum de Rolando Eötvös Nominatae, Sectio Biologica 14: 133-158.

Simon T., Kovácsné Láng E. 1972: Produkcióbiológiai vizsgálatok a csévharaszti IBP mintaterületen. Az MTA Biológiai Tudományok Osztályának Közleményei 15(1-2): 61-69.

Simon T., Mészáros-Draskovits R. 1972: The vegetation map of the nature reserve area of Csévharaszt in Hungary. Annales Universitatis Scientiarum de Rolando Eötvös Nominatae, Sectio Biologica 14: 159-164.

Simon T., Molnár A. 1972: A Crocus heuffelianus Herb. új észak-alföldi termőhelye. Botanikai Közlemények 59(3): 193-195.

Simon T., Orbán S. 1972: Untersuchung der Assimilationsfläche und des Chlorphyllgehaltes des Festuca vaginata-Rasens und der Roggensaat. Annales Universitatis Scientiarum Budapestiensis de Rolando Eötvös Nominatae, Sectio Biologica 14: 165-167.

Simon T. 1973: Botanicseszkie isszledovanije v Vengerszkih Zapovednikah. Naucsnaja Szesszi poszv. 25 letiju naucsno-techn. Szotrud. VNR i SZSZSZR. Szekcija zascsitü okruzsajiscsej szredü V. BME i ELTE TTK, Budapest, pp. 29-32.

Simon T. 1973: Brachyodontium trichodes (Web. f.) Bruch Síkfőkút közelében. Botanikai Közlemények 60(3): 163-166. 
Simon T. 1973: Megemlékezés Boros Ádámról (1900-1973). Botanikai Közlemények 60(1): 3-5.

Simon T. 1973: Obrazcovaje oblaszty Csévharaszt Mezsdunarodnoj Biologicseszkoj Programmü. Naucsnaja Szesszi poszv. 25 letiju naucsno-techn. Szotrud. VNR i SZSZSZR. Szekcija zascsitü okruzsajiscsej szredü V. BME i ELTE TTK, Budapest, pp. 17-24.

Simon T. 1974: Estimation of phytomass dry-weight of epiphytic mosses at Síkfőkút (near Eger, N Hungary). Acta Botanica Academiae Scientiarum Hungaricae 20(3-4): 341-348.

Simon T., 1974: Mohák, zuzmók, harasztok. Búvár Zsebkönyvek. Móra Ferenc Könyvkiadó, Budapest.

Simon T. 1974: Schätzung der Ökologie einiger Flechenarten auf Grund zönologischer und ökologischer Daten. Annales Universitatis Scientiarum de Rolando Eötvös Nominatae, Sectio Biologica 16: 145-153.

Simon T. 1974: Scrophulariaceae - Tátogatók. In: Boros Á.: Az ökörfarkkóró - Verbascum phlomoides L. Magyarország kultúrflórája V/20. Akadémiai Kiadó, Budapest, pp. 5-9.

Lásztity R., Parti M., László E., Simon T. 1975: A Budapesti Műszaki Egyetem és az Eötvös Loránd Tudományegyetem együttműködése a biológus-mérnök képzésben. Felsőoktatási Szemle 24(7-8): 457-463.

Simon T. 1975: A XII. Leningrádi Nemzetközi Botanikai Kongresszus és határozatai. Botanikai Közlemények 62(3): 227-230.

Simon T. 1975: A XII. Nemzetközi Botanikai Kongresszus Leningrádban. Búvár 30(10): 464.

Simon T. 1975: A természetes növénytakaró. A Kisalföld természetföldrajzi jellemzése; Természetes növényzet. A Győri-medence; A növénytakaró. A Komárom-Esztergomi-síkság; Természetes növényzet. A Marcal-medence. In: Ádám L., Marosi S. (szerk.) A Kisalföld és a Nyugat-magyarországi peremvidék. Magyarország tájföldrajza 3. Akadémiai Kiadó, Budapest, pp. 6672, 128-130, 169, 196-197.

Simon T. 1975: Hydrophyllaceae - Méhvirágfélék családja. In: Boros Á.: A mézontófü - Phacelia tanacetifolia Henth. Magyarország kultúrflórája IV/22. Akadémiai Kiadó, Budapest, pp. 5-7.

Simon T. 1975: Kutatási irányok, eredmények és feladatok a növényökológiában. In: Csaba Gy. (szerk.) A biológia aktuális problémái 4. Medicina Könyvkiadó, Budapest, pp. 53-111.

Simon T. 1975: Mosses as indicator organisms for soil conditions in steppe forest ecosystems. XII. International Botanical Congress, Leningrad, July 3-10, 1975. Abstracts. Nauka, Leningrad. Vol. I., p. 87.

Simon T. 1975: Novellia curvifolia (Dicks.) Mitt. a Bakonyban és más adatok a hazai mohaflórához. Abstracta Botanica 3: 105-111.

Simon T. 1975: Talajtani címszavak. In: Straub B. (szerk.) Biológiai Lexikon 1-4. kötet. Akadémiai Kiadó, Budapest.

Simon T., Egey A., Molnár A. 1975: Emlékezés Hargitai Zoltánra (1912-1945). Botanikai Közlemények 62(3): 159-163.

Simon T., Szerényi G. 1975: Moss ecological investigation in the forest-steppe associations of the IBParea at Csévharaszt. Acta Botanica Academiae Scientiarum Hungaricae 21(1-2): 117-136.

Dézsi L., Simon T. 1976: Investigation of the K-, Ca-, P-, N- and amino acid content of the epiphytic Hypnum cupressiforme. Acta Botanica Academiae Scientiarum Hungaricae 22(1-2): 17-28.

Simon, T., Kovács-Láng E. 1976: Phytomass production and environmental conditions of grasslands and soil at Csévharaszt. Polish Ecological Studies 2(2): 121-127.

Simon T. 1977: A Zempléni-hegység északi részének védendő flóra különlegességeiről. Abstracta Botanica 5: 57-63.

Simon T. 1977: Olvasóink levele nyomán - új növényritkaság hazánk flórájában! Búvár 32(2): 86.

Simon T. 1977: Vegetationsuntersuchungen im Zempléner Gebirge. Die Vegetation Ungarischer Landschaften Bd. 7. Akadémiai Kiadó, Budapest, 351 pp. 
Simon T. 1977: Zempléni hegységi sziklai és erdei növénytársulások határozókulcsa. Abstracta Botanica 5: 65-75.

Simon T., Horánszky A., J. Komlódi M., K. Láng E., M. Draskovits R. 1977: Növényrendszertani terepgyakorlatok. Egyetemi jegyzet. 3. változatlan kiadás. Tankönyvkiadó, Budapest, 139 pp., +1 térkép.

Simon T. 1978: Aizoaceae. Kristályvirágfélék (Jégvirágfélék) családja. In: Priszter Sz. (szerk.) Az újzélandiparaj, Tetragonia tetragonoides (Pall.) O. Ktze. Magyarország kultúrflórája VII/1. Akadémiai Kiadó, Budapest, pp. 5-7.

Simon T., Juhász-Nagy P., Láng E., Horánszky A., Tóth J. 1978: A Gabcsikovó-Nagymarosi Vízlépcsőrendszer létesítésével összefüggő biológiai egyensúly vizsgálata I. Jelentés. ELTE Növényrendszertani és Ökológiai Tanszék, Budapest. (Kézirat 10 példányban)

Horánszky A., Jakucs P., Láng E., Simon T. 1979: A Gabcsikovo-Nagymarosi és a Tisza II. vízlépcsőrendszerek ökológiai problémái. A Magyar Tudományos Akadémia Biológiai Tudományok Osztályának Közleményei 22(3-4): 407-414.

Horváth I., Mahunka S., Simon T., Szujkóné-Lacza J. 1979: Nemzeti parkok kutatása - Természetvédelem - Tájrekonstrukció. Az MTA Biológiai Tudományok Osztályának Közleményei 22(3-4): 337-350.

Simon T. 1979: A Duna-Tisza köze növénytakarójának történeti kialakulása. In: Tóth K. (szerk.) Nemzeti park a Kiskunságban. Natura, Budapest, pp. 165-178.

Simon T. 1979: Zönologische und ökologische Moospflanzenforschung in Ungarn. Abstracta Botanica 5(Suppl. 3): 33-42.

Simon T., Horánszky A., Kovács-Láng, E. 1980: Potentielle Vegetationskarte der Donaustrecke zwischen Rajka und Nagymaros. Acta Botanica Academiae Scientiarum Hungaricae 26(12): 191-201, +4 térkép.

Hortobágyi T., Simon T. (szerk.) 1981: Növényföldrajz, társulástan, ökológia. Tankönyvkiadó, Budapest, 546 pp. +2 térkép

Simon T. 1981: Az ökoszisztéma ökológiai alapjai. In: Hortobágyi T., Simon T. (szerk.) Növényföldrajz, társulástan, ökológia. Tankönyvkiadó, Budapest, pp. 434-476.

Simon T. 1981: Tájvédelmi körzetet Szigetköznek! Vízlépcsőrendszer és természetvédelem. Búvár 36(4): 155-158.

Simon T. 1982: Zempléni-hegységi növénytársulások ploidia viszonyai és szekunder jellege közötti összefüggések. Abstracta Botanica 7: 75-84.

Simon T., Csapody V. 1982: Kis növényhatározó rendszertani és ökológiai tájékoztatóval. 9. bővített kiadás. Tankönyvkiadó, Budapest, 204 pp.

Simon T., Láng, E., Juhász-Nagy, P. 1982: A Gabcsikovo-Nagymarosi Vízlépcsőrendszer (GNVR) létesítésével összefüggő ökológiai egyensúly vizsgálatának tapasztalatai. ATOMKI Közlemények 24(Suppl. 1.): 17-22.

Simon, T., Szőke, Z. 1982: Obrazcovaje oblaszty Csévharaszt Mezsdunarodnoj Bioszfernüe zapovedniki Vengerszkoj Narodno Reszpubliki. Szbornik: Ekol. Monitorinh v bioszfernüh zapovednikah szocialiszticseszkih sztran. Puscsino, pp. 256-273.

Simon T. 1983: Egyes címszavak. In: Priszter Sz. (szerk.) Arbores Fruticesque Europae. Vocabularium Octo Linguis Redactum - Európa fái és cserjéi. Nyolcnyelvü szótár. Akadémiai Kiadó, Budapest, 300 pp.

Simon T. 1984: A Bugaci Bioszféra Rezervátum edényes flórájának természetvédelmi értékelése. Abstracta Botanica 8: 95-100.

Simon T. 1984: Természetvédelmi célú botanikai kutatás a Bükki Nemzeti Parkban (1980-1985). Az erdő 33(6): 251-256. 
Simon T., Koltay A. 1984: Baráth Zoltán emlékére (1924-1982). Botanikai Közlemények 71(1-2): $1-6$.

Simon T. 1984. A növényzetről. In: Szeremley Sz. (szerk.) Zempléni Tájvédelmi Körzet. Országos Természetvédelmi Hivatal Észak-Magyarországi Felügyelőség, Miskolc, pp. 19-27.

Simon T. 1985: A Knautia dipsacifolia Kreutzer védett montán faj az Északi-Alföldön. Botanikai Közlemények 72(1-2): 123-124.

Simon T. 1985: A magyar flóra kézikönyve (Soó Rezső életműve). Tudomány. A Scientific American magyar kiadása. 1985/4: 50-51.

Simon T. 1985: The leaf area index of three moss species. Abstracta Botanica 9(Suppl. 1): 46.

Simon T., Juhász-Nagy P., Rajkai K., Járai-Komlódi M., Konecsni I., Horánszky A., Hahn I., Szabó M., Láng E., Ravasz K., Márialigeti K. 1985: Az ELTE Növényrendszertani és Ökológiai Tanszéke komplex ökológiai kutatásai. In: Tóth K., Szabó L. (szerk.) Tudományos kutatások a Kiskunsági Nemzeti Parkban 1975-1984. HUNGEXPO, Budapest, pp. 140-172.

Simon T., Szerényi G. 1985: A study of soil characteristics under moss tufts in the acid sand area of Somogy county, Hungary. Abstracta Botanica 9(Suppl. 2): 205-217.

Dézsi L., Simon T. 1986: Nutrient content of dominant epiphytic moss (Hypnum cupressiforme). In: Jakucs P. (ed.) Ecology of an oak Forest in Hungary. Results of „Síkfökút Project”. Akadémiai Kiadó, Budapest, pp. 374-382.

Pócs T., Simon T., Tuba Z., Podani J. (eds) 1987: Proceedings of the IAB Conference of Bryoecology. Parts A \& B. Symposia Biologica Hungarica 35, Akadémiai Kiadó, Budapest, 902 pp.

Simon T. 1987: Metodü za zascsita na prirodata v Ungarija. Nature Conservations methods in Hungary. In: Kusmanov B. (ed.) Proceedings of the Fourth National Conference of Botany, Sofia, Bulgaria, pp. 430-440. [in Bulgarian with English summary]

Simon T. 1987: The leaf area index of three moss species (Tortula ruralis, Ceratodon purpureus, Hypnum cupressiforme). In: Pócs T., Simon T., Tuba Z., Podani J. (eds) Proceedings of the IAB conference of bryoecology, Symposia Biologica Hungarica 35. Akadémiai Kiadó, BudapestVácrátót, Hungary, pp. 699-706.

Simon T. 1988: A hazai edényes flóra természetvédelmi-érték besorolása. Abstracta Botanica 12: $1-23$.

Simon T. 1988: Tiszán innen, Tiszán túl: Változó flóra. Búvár 43(11): 2-4.

Simon T. 1988: Tiszán innen, Tiszán túl. Búvár 43(11): 18-19.

Simon T., Láng E. 1988: Programme for biological monitoring in the region of the GabcikovoNagymaros barrage system. Abstracta Botanica 12: 65-72.

Simon T., Kovács-Láng E. 1989: Phytoindication of changes in karstic water level. BIOS (Thessaloniki) Ganiatsas Memorial Volume: 231-244.

Simon T., Kovács-Láng E. 1989: Szoszdanie szisztemü biologicseszkovo monitoringa ozsidaemüh vozgyejtszvij na okrozsajucsuju szredi szooruzsenija kaszkada elektrosztancij na Dunae v rajone Gabcsikovo-Nagymaros. Ekol. Koop. Inf. Bjul. po probleme III. Ohrana ekoszisztem (biogeocenozov). Bratislava 1-2: 77-81.

Simon T. 1990: Biomonitoring fitoindikációs módszere. In: Dobos T., Galambos J. (szerk.) Környezetállapot-változás monitoring és információs rendszere. MTA Földrajztudományi Kutató Intézet, Budapest, pp. 101-115.

Kovács M., Moskát Cs., Simon T. 1991: Tanulmányok hazánk környezeti állapotáról. IV. Az élővilág. Környezet és fejlődés 2(6-7): 73-75.

Mőcsényi M., Kovács M., Kecskeméti T., Mahunka S., Csima P., Simon T. 1991: A védett természeti értékek. Környezet és fejlődés 2(6-7): 80-84. 
Simon T. 1991: A Biológiai Tanszékcsoport előzményei és története (1973-1985). In: Priszter Sz. (szerk.) Az Eötvös Loránd Tudományegyetem Természettudományi Karának története. 1635-1985. Eötvös Loránd Tudományegyetem, Budapest, pp. 41-56.

Simon T. 1991: A complex study of supraindividual organization. Spatial and temporal investigations of biotic communities. In: Lázár G. (ed.) Advances in Biological Research in Hungary 1986-1990. Ecology. Budapest, pp. 3-6.

Simon T. 1991: A cönológia és ökológia vázlata. In: 100 éves a Magyar Biológiai Társaság Botanikai Szakosztálya 1891-1991. Budapest, 1991 augusztus 21., Biotár VII. (Budapest - Szombathely), p. 26.

Simon T. (szerk.) 1991: Baktérium, alga-, gomba-, zuzmó- és mohahatározó. Tankönyvkiadó, Budapest, $793 \mathrm{pp}$.

Simon T. 1991: Növényfajok és társulások természetvédelmi értékének becslése. Természetvédelmi Közlemények 1(1): 99-114.

Simon T., Horánszky A., J. Komlódi M., K. Láng E., M. Draskovits R. 1991: Növényrendszertani terepgyakorlatok. Egyetemi jegyzet. 6. változatlan kiadás. Tankönyvkiadó, Budapest, 139 pp., +1 térkép.

Simon T., Kefeli V. I. 1991: Dinamika resztyityeljnovo vesesztva i szovremennie pocsvennüe processzi v travjanüsztih ekoszisztemah. (Dynamics of primary production and soil processes in grassland ecosystems) Akademija Nauk SzSzSzR, Puscsino, 236 pp.

Stoyko S. M., Hadach E., Simon T., Mikhalik S. 1991: Zapovidni ekoszisztemi Karpat. (Protected ecosystems in the Carpathians). Svit, Lviv, $247 \mathrm{pp}$.

Standovár T., Tóth Z., Simon T. 1991: Vegetation of the Bátorliget Mire Reserve. In: Mahunka S. (ed.) The Bátorliget Nature Reserves - after forty years. Hungarian Natural History Museum, Budapest, pp. 57-118.

Simon T. 1992. A magyarországi edényes flóra határozója. Harasztok - virágos növények. (1. kiadás, változatlan 2. kiadás 1994., 3. kiadás 1996.), Tankönyvkiadó, ill. Nemzeti Tankönyvkiadó, Budapest, 892 pp.

Simon T. 1992: A Szigetköz növénytársulásai és azok természetessége. Természetvédelmi Közlemények 2: 43-55.

Simon T. 1992: Korpafüvek a Zempléni hegységben. In: A „Lippay János” tudományos ülésszak előadásai és poszterei. Környezettudomány. A Kertészeti és Élelmiszeripari Egyetem Kiadványai, Budapest, pp. 220-223.

Simon T. 1992: Tudományos követelmény: a sokféleség megőrzése. Természetbúvár 47(1): 32-33.

Simon T. 1992: Vegetation change and the protection of the Csaroda relic mires, Hungary. Acta Societatis Botanicorum Poloniae 61(1): 63-74.

Simon T., Fekete G., Török K. 1992: Phytosociology in establishing, monitorimg and reconstruction of nature reserves in Hungary. 35th International Symposium of IAVS, Shanghai. Abstracts, pp. 153-154.

Simon T., Horánszky A., Dobolyi K., Szerdahelyi T., Horváth F. 1992: A magyar edényes flóra értékelő táblázata. In: Simon T. (szerk.) A magyarországi edényes flóra határozója. Harasztok - virágos növények. Tankönyvkiadó, Budapest, pp. 791-874.

Simon T., Sasvári L. 1992: Botanikai és madártani megfigyelések a Szigetközben. Szigetközi Ankét, Magyar Hidrológiai Társaság, Győr 1992, pp. 221-231.

Bartha S., Csapody I., Dános B., Fekete G., Gallé L., Holly L., Horváth F., Jenser G., Kereszty Z., Kovács Gy., Németh F., Papp L., Simon T., Surányi D., Szabó T. A., Szőcs Z., Varga Z. 1993: Nemzeti biodiverzitás-megőrzési stratégia. Magyar Tudomány 38(8): 983-1010.

Simon T. 1993: Juhász-Nagy Pál (1935-1993). Magyar Tudomány 100(11): 1361-1362. 
Simon T. 1993: Növényállományok fitoindikációjának elemzése. Növényállományok természetvédelmi értékének elemzése. Növényzeti egységek térszíni transzekt felvételezése, profilrajza természetvédelmi területeken. Növényállományok térszíni felvételezése. In: Lenkei I. (szerk.) Szünbiológiai terepgyakorlatok I. Egyetemi jegyzet. ELTE, Budapest, pp. 31-36, 37-42, 59-66, 107-109.

Simon T., Horánszky A., J. Komlódi M., K. Láng E., M. Draskovits R. 1993: Növényrendszertani terepgyakorlatok. (Egyetemi jegyzet.) 7. változatlan kiadás. Nemzeti Tankönyvkiadó, Budapest, 139 pp., +1 térkép.

Simon T., Láng E. 1993: Környezet. Ökológia címszavakban. Természetbúvár 48(6): 36-37.

Simon T., Szabó M., Draskovits R., Hahn I., Gergely A. 1993: Ecological and phytocenological changes in the willow woods of Szigetköz, NW Hungary, in the past 60 years. Abstracta Botanica 17: 179-186.

Simon T. 1993: Egyes címszavak. In: Láng I. (főszerk.), Bándi Gy., Börzsónyi M., Hardi P., Jászay T., Kőrös E., Perczel Gy., Petres Gy., Simon T., Stefanovits P., Szebényi I. (szerk.) 1993: Környezetvédelmi lexikon I-II. Akadémiai Kiadó, Budapest, 530 pp., 483 pp.

Bartha S., Csapody I., Dános B., Fekete G., Gallé L., Holly L., Horváth F., Jenser G., Kereszty Z., Kovács Gy., Németh F., Papp L., Simon T., Surányi D., Szabó T. A., Szőcs Z., Varga Z. 1994: Foundation for developing a national strategy of biodiversity conservation. Acta Zoologica Academiae Scientiarum Hungaricae 40(4): 289-327.

Mészáros F., Simon T., Ronkay L., Báldi A., Vida G. 1994: The description of the ecological values of the Szigetköz inland delta. In: International Court of Justice, Case concerning the Gabčikovo-Nagymaros Project (Hungary-Slovakia), Counter-Memorial of the Republic of Hungary. Annexes, Scientific reports and studies, vol. 4 (part 2), pp. 746-757.

Mészáros F., Simon T., Ronkay L., Vida G., Báldi A. 1994: The characterisation and the threat to terrestrial and partially aquatic habitats, the impact of GNBS and within that, of Variant "C". In: International Court of Justice, Case concerning the Gabčikovo-Nagymaros Project (Hungary-Slovakia), Counter-Memorial of the Republic of Hungary. Annexes, Scientific reports and studies, vol. 4 (part 2), pp. 724-745.

Simon T. 1994: Boros Ádám, a flórakutató. In: Papp B. (szerk.) A Boros Ádám emlékülésen elhangzott előadások anyaga. Studia botanica hungarica 25: 94-95.

Simon T. (szerk.) 1994: Természeti kincsek Dél-Budán. A Tétényi-fennsík és a Háros-sziget növény- és állatvilága, természetvédelme. Flora, vegetation, fauna and their conservation in the Tétényi-Plateau and Háros-Island. Cserépfalvi Kiadó - Zöld Jövő, Budapest, 96 pp.

Molnár E., Simon T., Szabó M., Iványosi-Szabó A. 1995: Some aspects of the management of sandy areas in the Kiskunság National Park, Hungary. Proceedings of the 1st Conference of EgyptHungary on Environment, Ismailia, Egypt (1993), pp. 187-198.

Simon T. 1995: A tündérrózsák és a flóra jelzései a Hévízi-tó veszélyeztetett állapotáról. In: „Régi fénynél új szövétneket", Hévízi Könyvtár 6, Hévíz, pp. 138-143.

Simon T. 1995: Természetvédelmünk helyzete. Virágok, erdők, rétek és a természetvédelem. Természet Világa 126(II. különszám): 32-35.

Simon T., Szabó M. 1995: Impact of the Gabčikovo-Nagymaros Project on vegetation in the Szigetköz. In: International Court of Justice, Case concerning the Gabčikovo-Nagymaros Project (Hungary/Slovakia). Reply of the Republic of Hungary, vol. 3, Annexes, pp. 55-75.

Simon T., Szabó M. 1995: Wetland ecology and vegetation. In: International Court of Justice, Case concerning the Gabčikovo-Nagymaros Project (Hungary/Slovakia). Reply of the Republic of Hungary, vol. 2. Scientific rebuttal, Appendices, pp. 47-56. (with 3 coloured vegetation maps). 
Hahn I., Szabó M., Simon T., Draskovits R., Gergely A., Molnár E. 1997: Vegetation succession in the exposed Danube bed. In: Láng I., Banczerowski I., Berczik Á. (eds) Studies on the environmental state of the Szigetköz after the diversion of the Danube. MTA Szigetköz Bizottság, Budapest, pp. 75-82.

Simon T. 1997: Angolpázsit vagy pannon rét? Természet Világa 128(8): 374-376.

Simon T. 1997: Az edényes flóra kutatása a flóraművek tükrében. Botanikai Közlemények 84(1-2): $17-24$.

Szabó M., Simon T., Hahn I., Gergely A., Draskovits R. 1997: Changes in the natural vegetation of the Szigetköz following the Danube Diversion. In: Láng I., Banczerowski I., Berczik Á. (eds) Studies on the Environmental state of the Szigetköz after the diversion of the Danube. MTA Szigetköz Bizottság, Budapest, pp. 61-75.

Simon T., Seregélyes T. 1998: Növényismeret. A hazai növényvilág kis határozója. Nemzeti Tankönyvkiadó, Budapest, 276 pp.

Dosztányi I., Simon T. 1999: Közhasznúsági jelentés - szavakban, számokban: TermészetBÚVÁR Alapítvány 1998. Természetbúvár 54(4): 9.

Simon T. 1999: Debrecentől Budapestig (1945-1953). In: Emlékbeszédek az MTA elhunyt tagjai felett. Soó Rezső (1903-1980). Magyar Tudományos Akadémia, Budapest, pp. 16-21.

Simon T. 1999: Poaceae (Gramineae) - Pázsitfüfélék. In: Czimber Gy., Varga J. (szerk.) A rozsnok - Bromus L. fajok. Magyarország kultúrflórája VIII/4. Akadémiai Kiadó, Budapest, pp. 7-24.

Simon T. 1999: Vadnyugati erdők és virágok. Se-Quo-Yah irokéz indián fái. Természetbúvár 54(5): 32-33.

Gergely A., Hahn I., Barabás S., Mészárosné Draskovits R., Simon T. 2000: A növényzet szukcessziója a Duna kiszáradt medrében. Acta biologica Debrecina. Supplementum oecologica hungarica 11: 224.

Hahn I., Simon T., Draskovits R., Szabó M., Gergely A., Barabás S. 2000: A szigetközi botanikai monitorozás tapasztalatai. Acta biologica Debrecina. Supplementum oecologica hungarica 11(1) 66.

Hortobágyi T., Simon T. (szerk.) 2000: Növényföldrajz, társulástan és ökológia. 3., részben átdolgozott kiadás. Nemzeti Tankönyvkiadó, Budapest, 538 pp.

Simon T. 2000: A magyarországi edényes flóra határozója. Harasztok - virágos növények. 4., átdolgozott kiadás. Nemzeti Tankönyvkiadó, Budapest, 976 pp.

Simon T. 2000: Boros Ádám, Juhász-Nagy Pál, Papp József, Szatala Ödön. In: Bartha D., Csapody I., Szodfridt I. (szerk.) Mestereink. Ilyennek láttuk őket. Emlékmorzsák a közelmúlt jeles botanikusairól. Tilia 8: 16-17, 44-45, 64-65, 110.

Simon T. 2000: Századvégi leltár: eltékozolt és felfedezett növényeink. Természetbúvár 55(6): 10-12.

Balogh L., Simon T., Szabó M., Vidéki R. 2001: Új adventív növény a hazai flórában: a sárga bohócvirág (Mimulus guttatus Fischer ex DC., Scrophulariaceae). Kitaibelia 6(2): 329-345.

Simon T. 2001: A havasi varázslófü (Circaea alpina L.) hazai cönológiája. Botanikai Közlemények 88(1-2): 107-116.

Simon T. 2001: A magyarországi edényes flóra határozója. Harasztok - virágos növények. 4. átdolgozott és kisalakú („zseb”) kiadás. Nemzeti Tankönyvkiadó, Budapest, 846 pp.

Simon T. 2001: Pali, az ifjú botanikus. Kitaibelia 6(2): 221-224.

Simon T. 2002: Halhalál és a többiek: botanikai nyomozás. Természetbúvár 57(4): 32-33.

Simon T. 2002: Egyes címszavak. In: Láng I. (főszerk.) Környezet- és természetvédelmi lexikon I-II. Akadémiai Kiadó, Budapest, 664 pp., 588 pp.

Simon T. 2003: A Lunularia cruciata (L.) Lindb. régi-új hazai termőhelye. Acta Academiae Paedagogicae Agriensis, Sectio Biologiae 24: 129-136. 
Simon T. (szerk.) 2003: Baktérium-, alga-, gomba-, zuzmó- és mohahatározó. 2. átdolgozott kiadás. Nemzeti Tankönyvkiadó, Budapest, 832 pp.

Simon T. 2003: Rezső Soó the prominent Hungarian scientist of the twentieth century was born 100 years ago (1903-1980). Száz éve született Soó Rezső, a huszadik század kiemelkedő magyar tudósa. Kanitzia 11:7-14.

Simon T. 2004: A vegetáció és változásai hazánkban és környezetében az első évezred fordulója óta. In: Dövényi Z., Schweitzer F. (szerk.) Táj és környezet. Tiszteletkötet a 75 éves Marosi Sándornak. MTA Földrajztudományi Kutató Intézete, Budapest, pp. 31-44.

Simon T. 2004: Gyeptársulások indikációi. Gyepgazdálkodási Közlemények 2004/2: 25-27.

Simon T. 2004: Szép emlékeim a Csarodai-lápokról. Szabolcs-Szatmár-Beregi Szemle 39(2): 132-137.

S. Wolcsánszky E., Simon T. 2004: Suba Jánost köszöntjük. Acta Academiae Paedagogicae Agriensis, Sectio Biologiae XXV: 5-8.

Simon T. 2005. Adatok a Białowieza Nemzeti Park mohaindikációjához. Acta Academiae Paedagogicae Agriensis. Sectio Biologiae 32: 36-46.

Simon T. 2005: Adatok a Zempléni-hegység flórájához (1950-1980) és a Carpaticum-flórahatár kérdése. Botanikai Közlemények 92(1-2): 69-84.

Simon T. 2005: Botanikai útinaplóim Zempléni-hegységi adatai (1954-1967). Kanitzia 13: 11-28.

Simon T. 2005: Hetven éve született Juhász-Nagy Pál: időtálló életmű. Természetbúvár 60(6): 19.

Simon T. 2006: A Zempléni-hegység botanikai értékei. Folia Historico-Naturalia Musei Matraensis 30: 407-414.

Simon T. 2006: Szabolcs-Szatmár-Bereg megye növényvilága. A Csarodai tavak felfedezése. In: Lenti I. (szerk.) A természet kincsei Szabolcs-Szatmár-Bereg megyében. Szabolcs-SzatmárBereg Megyei Közgyülés, Nyíregyháza, pp. 15-40.

Simon T. 2007: Adatok a Déli-Kárpátok alhavasi cserjéseinek cönológiájához és természetességéhez. Botanikai Közlemények 94(1-2): 117-131.

Simon T., Matus G., Pelles G., Tóth Z., Vojtkó A. 2007: Növényvilág, növénytani értékek. In: Baráz Cs., Kis G. (szerk.) A Zempléni Tájvédelmi Körzet - Abaúj és Zemplén határán. Bükki Nemzeti Park Igazgatóság, Eger, pp. 111-140.

Simon T., Podani J. 2007: Régi-új faj, az Euphorbia segetalis L. a magyar flórában. Kitaibelia 12(1): 121-123.

Simon T. 2008: Die Florawelt des comitates Szabolcs-Szatmár-Bereg. Entdeckung der Csaroder Teiche. In: Lenti I. (ed.) Die Schätze der Natur im Komitat Szabolcs-Szatmár-Bereg. SzabolcsSzatmár-Bereg Megyei Közgyülés, Nyíregyháza, pp. 33-42.

Simon T. 2008: Flora of the counties Szabolcs-Szatmár-Bereg. Discovery of the Csaroda-Mires. In: Lenti I. (ed.) Treasures of nature in Szabolcs-Szatmár-Bereg county. Szabolcs-Szatmár-Bereg County Assembly, Nyíregyháza, pp. 15-40.

Simon T. 2008: Jávorka Sándor emlékére. Természetbúvár 63(2): 18-19.

Simon T. 2008: Láng Editet, volt munkatársamat (1963-1998) köszöntöm. In: Kröel-Dulay Gy., Kalapos T., Mojzes A. (szerk.) Talaj-vegetáció-klíma kölcsönhatások. Köszöntjük a 70 éves Láng Editet. MTA Ökológiai és Botanikai Kutatóintézete, Vácrátót, pp. 221-225.

Simon T. 2009: Adatok a Déli-Kárpátok alhavasi és havasi szőrfügyep és örökzöldsásos növényzetének cönológiájához és természetességéhez. Kanitzia 16: 7-24.

Simon T. 2009: Botanikai címszavak. In: Frisnyák S., Gál A., Horváth G. (szerk.) A Zemplénihegység földrajzi lexikona. Nyíregyházi Főiskola Turizmus és Földrajztudományi Intézete, Nyíregyháza-Szerencs, 429 pp.

Simon T. 2009: Data about the flora of Zemplén Mountains (1950-1980) and the question of the Carpaticum flora boundary. Thaiszia - Journal of Botany, Koşice 19(Suppl. 1): 19-36. 
Simon T. 2009: The botanical assets of the Zemplén Mountains. Thaiszia - Journal of Botany, Koşice 19(Suppl. 1): 5-18.

Simon T. 2009: Villámlátogatás a vadnyugati virágoknál. Természet Világa 140(9): 409-412.

Simon T. 2012: A Zempléni hegység, a határos Hernád- és Bodrog-völgy növényvilágának kutatása. In: Gál A. (szerk.) A Zempléni-hegység tudományos feltárói és gazdaságfejlesztői. Tanulmánygyüjtemény. A Nyíregyházi Főiskola Turizmus és Földrajztudományi Intézete és a szerencsi Bocskai István Gimnázium, Nyíregyháza - Szerencs, pp. 256-280.

Simon T., Pócs T. 2012: New aspects of the alpine vegetation of Parâng Mountains (South Carpathians). Journal of Plant Development 19: 99-129.

Simon T., Pócs T. 2012: Tanulmányok a déli-kárpáti Páreng-hegység havasi vegetációján. Kitaibelia $17(1): 53$.

Simon T. 2013: Priszter Szaniszló: tudás, szerénység, segítőkészség, fáradhatatlan munkálkodás. Kitaibelia 18(1-2): 23-25.

Simon T., Lakatos E. 2013: A Szerencsi-dombság lejtősztyeppje: Pulsatillo montanae-Festucetum rupicolae. In: Frisnyák S., Gál A. (szerk.) Kárpát-medence: természet, társadalom, gazdaság (földrajzi tanulmányok). Nyíregyházi Főiskola Turizmus és Földrajztudományi Intézete és a szerencsi Bocskai István Gimnázium, Nyíregyháza-Szerencs, pp. 113-122.

Simon T., Pócs T. 2013: Cönológiai adatok a déli-kárpáti Páreng-hegység havasi vegetációjához. Botanikai Közlemények 100(1-2): 103-133.

Simon T., Siklósi E. 2013: Adatok a Zemplén-hegységi szubmontán égerligetek cönológiájához. Kanitzia 20: 89-99.

Simon T., Csontos P. 2016: Horánszky András egyetemi docensre, a biológiai tudományok kandidátusára emlékezünk (1928-2015). Botanikai Közlemények 103(2): 179-183.

\section{Szakfordítói tevékenysége}

Kremer B., Muhle H. 2000: Zuzmók, mohák, harasztok. Fordította és a hazai vonatkozásokkal kiegészítette Simon T. Magyar Könyvklub, Budapest, 287 pp.

\section{Közlemények Simon Tiborról}

Ötvös Z. 1994: Tudósok Eötvös Koszorúval. Simon Tibor. Népszabadság 52(230): 24. (1994. október 1.)

Anonymus 1995: Az Eötvös József Koszorú kitüntetettjei. Dr. Csepregi Pál, a mezőgazdasági tudomány doktora, a Kertészeti és Élelmiszer-ipari Egyetem egyetemi tanára. Dr. Simon Tibor a biológiai tudományok doktora, az Eötvös Loránd Tudományegyetem Növényrendszertani és Ökológiai Tanszék egyetemi tanára. Természet Világa 126(4): 149-151.

Bácsy A., Albert É., Vigh K., Pócs T., Draskovits R. 1996: Köszöntés. Simon Tibor 70 éves. A Botanikai Szakosztály 1312. szakülésén (1996. október 7.) elhangzott előadás kivonata. Botanikai Közlemények 83(1-2): 175-176.

Hetényi P.-né, Erdélyiné Holdas K. (szerk.) 1999: Környezetvédelmi Kalauz 1999. Környezetgazdálkodási Intézet - Országos Müszaki Információs Központ és Könyvtár, Budapest, p. 113.

Mészárosné Draskovits R. 2001: Simon Tibor 75 éves. Botanikai Közlemények 88(1-2): 13-14.

Csohány E. K. 2005: Simon Tibor botanikus különlenyomat-gyüjteményének adatbázisa. Szakdolgozat a Berzsenyi Dániel Főiskola Természettudományi Főiskolai Karon, Szombathely, 45 pp. (CD-ROM melléklettel) 
Draskovits R. 2006: Volt egy csapat... Tisztelgés a 80 éves Simon Tibor Professzor Úr előtt. In: Kalapos T. (szerk.) Jelez a flóra és a vegetáció. A 80 éves Simon Tibort köszöntjük. Scientia, Budapest, pp. 181-182.

Horánszky A. 2006: Simon Tibor 80 éves! In: Kalapos T. (szerk.) Jelez a flóra és a vegetáció. A 80 éves Simon Tibort köszöntjük. Scientia, Budapest, pp. 181-186.

Kalapos T. (szerk.) 2006: Jelez a flóra és a vegetáció. A 80 éves Simon Tibort köszöntjük. Scientia, Budapest, 190 pp.

Szerényi G. 2006: Köszöntő. In: Kalapos T. (szerk.) Jelez a flóra és a vegetáció. A 80 éves Simon Tibort köszöntjük. Scientia, Budapest, pp. 187-190.

Anonymus 2010: A hűség hármasa. Szily Kálmán-emlékérmeseink - 2009. Járainé Komlódi Magda, Abonyi Iván, Simon Tibor. Természet Világa 141(1): XIV-XV.

Marschall Z. 2012: Dr. Simon Tibor botanikai kutatómunkája a Zempléni-hegységben. In: Gál A. (szerk.) A Zempléni-hegység tudományos feltárói és gazdaság fejlesztői. Nyíregyházi Főiskola Turizmus és Földrajztudományi Intézete és a szerencsi Bocskai István Gimnázium, Nyíregyháza - Szerencs, pp. 295-302.

Draskovits R., Láng E. 2016: Hazánk zöld palástjának tudósa. A 90 esztendős Simon Tibor. Természetbúvár 71(4): 32-35.

Isépy I. 2017: Simon Tiborral a Füvészkertben és a terepgyakorlatokon, a Nagyszénástól KözépÁzsiáig. (A 90 éves Simon Tibor köszöntése.) A Magyar Biológiai Társaság Botanikai Szakosztályának 1475. szakülésén (2016. október 17.) elhangzott előadás kivonata. Botanikai Közlemények 104(1): 165-166.

A természetbúvár Alapítvány munkatársai 2020: Búcsú a tudóstól, tanártól, elnökünktől (dr. Simon Tibor). TermészetBúvár 75(6): 2.

Dihoru, G. 2020: Ártéri kutatással indult - Közös botanizálások Simon Tiborral. Élet és Tudomány 75(49): 1549. (Magyarra fordította: Kovács J. Attila; Megjelent 2020. december 4-én.)

\section{Simon Tibor témavezetésével készült szakdolgozatok, disszertációk} (a jegyzék nem teljes)

Szakdolgozatok: Láng Edit: Termőhelyvizsgálatok akácosított gyertyános-tölgyesekben. (1961; 34 pp.) - Petri Ilona: A külső-somogyi Gamás község környéki erdők cönológiai, talajökológiai viszonyai és flórája. (1963; 56 pp.) - Fülöp András: Festucetum vaginatae normale és Festucetum vaginatae stipetosum szubasszociáció összehasonlítása talajökológiai alapon. (1964; 34 pp.; társtémavez.: Kovácsné Láng Edit) - Molnár Edit: A Csiki-hegyek tölgyeseinek helyére ültetett feketefenyő hatására bekövetkezett cönológiai és talajökológiai változások. (1964; 33 pp.) - Hauer Rudolf: Különböző termőhelyekről származó növények (Dianthus pontederae és Diplachne serotina) összehasonlító elemzése. (1965; 30 pp.; társtémavez.: Kovácsné Láng Edit) - Horák Endre: Nyílt sziklagyep karsztbokorerdő és mészkedvelő tölgyes állományok humuszának vizsgálata a Nagykevélyen. (1965; 41 pp.; társtémavez.: Kovácsné Láng Edit) - Héra Györgyné: A poliploidia és a termőhely néhány ökológiai tényezője közötti összefüggés vizsgálata. (1970; 58 pp.) - Galambos István: A kálium és kalcium ionok mennyiségének szezonális változása és összefüggése a környezeti tényezőkkel a homoki gyepek zuzmó fajaiban. (1971; 60 pp.) - Rimóczi Imre: Mikorrhizás gombák micéliumtenyészeteinek növekedése avar- és gyökérkivonatok hatására. (1971; 93 pp.) - Oláh Béla: A magyarországi Orthotrichumok határozókulcsa, areálgeográfiája és cönológiája. (1974; 69 pp.) - Farkas József: Rétek és legelők egyes ökológiai jellemzőinek összehasonlító vizsgálata a Hernád-ártéren. (1975; 75 pp.) - Stiebel Alice: Talajalgológiai vizsgálatok a csévharaszti IBP mintaterületén. (1975; 41 pp.) - Siklósi Engelbert: A zempléni égerligetek cönológiai vizsgálata. (1977; 30 pp.) - Susa Ágnes, Szabó Tamás: A Tóth-árok növénytani és talajfaunisztikai felmé- 
rése. (1979; 64 pp.) - Sipos György: Az erdő- és gyeptársulások degradációja a Budai Tájvédelmi Körzet területén. (1984; 43 pp.) - Zentai László: Komplex méretarányú növényföldrajzi térképezés (Csepel, Tamariska-domb). (1984; 77 pp.) - Standovár Tibor: Növényzet- és talaj-mintázat összehasonlító elemzése a nyugat-mátrai Nyikom-réten. (1986; 41 pp.) - Egri Károly: Mikológiai megfigyelések a Zempléni-hegységben. (1988; 60 pp.) - Both Mária, Mondok Zsuzsa: Botanikai vizsgálatok egy felhagyott homokbányában. (1989; 36 pp.; társtémavez.: Seregélyes Tibor) - Albert Éva: A Sásdi-rétek botanikai értékei és javaslat megőrzésükre. (1990; 67 pp.) - Morschhauser Tamás: A Remete-szurdok flórája, vegetációja és degradáltsági állapotának felmérése. (1990; 57 pp.; társtémavez.: Horváth Ferenc) - Czumpf Attila, Puskás Zsigmond, Surman Mihály: A természeti értékek megőrzésének néhány környezetgazdálkodási lehetősége Magyarországon. (1992; 83 pp.) - Aszalós Réka: A vegetáció domborzatfüggésének vizsgálata a Visegrádi-hegységben. (1995; 31 pp.; témavez.: Horváth Ferenc, szakmai konzulens: Simon Tibor) - Tatár Dóra: Ökológiai vizsgálatok egy sípálya gyepjén. (1995; 27 pp.)

Doktori értekezések: Lakatos Endre: A szerencsi Szigethegység és a határos Hernád-völgy növénytársulásai I-II. kötet. (1967; 203+203 pp.) - Malatinszky Gyula: Őszi búza termőhelyek talaj-ökológiai vizsgálata. (1970; 138 pp.) - Seregélyes Tibor: Asszociáltság-analízis alkalmazása növénycönológiai tabellákra. (1974; 77 pp.; társtémavez.: Juhász-Nagy Pál) - Oláh Béla: A magyarországi Orthotrichumok (Musci) legfontosabb morfológiai, taxonómiai és ökológiai sajátságai. (1976; 189 pp.) - Török Katalin: Budapest sorfáinak elemtartalom vizsgálata. (1979; 122 pp.) - Szablics Mária: A középiskolai ökológia tananyag egyes részeinek módszertani feldolgozása, tanórára lebontva. (1981; 85 pp.) - Standovár Tibor: Vegetation studies and their applications to site indication in a Sessile Oak forest. (1993; 89 pp.)

\section{In memoriam Tibor Simon (1926-2020)}

\section{P. CSONTOS ${ }^{1}$, T. KALAPOS ${ }^{2, \S}$, T. PÓCS ${ }^{3}$, J. PODANI ${ }^{2, \#}$}

${ }^{1}$ Institute of Soil Science, Centre for Agricultural Research,

H-1022 Budapest, Herman Ottó út 15, Hungary; cspeter@mail.iif.hu

${ }^{2}$ Department of Plant Systematics, Ecology and Theoretical Biology, Institute of Biology, Eötvös Loránd University, H-1117 Budapest, Pázmány P. sétány 1/C, Hungary;

stibor.kalapos@ttk.elte.hu, " podani@caesar.elte.hu

${ }^{3}$ Department of Botany and Plant Physiology, Institute of Biology, Eszterházy Károly

University, H-3301 Eger, Pf. 43, Hungary; pocs.tamas33@gmail.com

Accepted: 20 April 2021

Key words: botany, history of science, bibliography, obituary.

At an age of 94, Professor Tibor Simon deceased on 26 November 2020. He was an outstanding scholar of Hungarian botany, a versatile researcher, a devoted teacher, a tireless advocate of fondness and protection of plants, and an unforgettable friend for many. He was born in Debrecen in 1926 and started his botanical 
career there at the university in the school of Professor Rezső Soó. Intensive fieldwork in the northeastern part of the country paid him national reputation with the discovery of a peat bog containing several rare glacial relict plant species, near the village Csaroda. In 1955, he followed his mentor to the Eötvös Loránd University in Budapest, where he remained for the rest of his life. He had the gift of unmatched productivity in several areas of botany, including floristics, plant geography, phytosociology, bryology and plant ecology. In addition to more than two hundred research papers and book chapters, his oeuvre contains the Vascular Flora of Hungary and exhaustive monographs on the vegetation of the Northern Great Plain and the Zemplén Mountains. As a university lecturer, he introduced several disciplines new for the students of the time (e.g. soil science, plant ecology) and taught others (e.g. plant systematics, phytogeography, phytosociology) with a high standard. He considered field work to be particularly important in university education. Many of his students gained unforgettable experience in field trips organized to various parts of the country and to the one-time Soviet Union. His contribution to popularizing plant science was outstanding. Not only about one-fourth of his publication list is of such writings, but generations of schoolchildren and the general public learned plants from the little Hungarian Flora he prepared with the excellent plant illustrator Vera Csapody. His role in providing expert knowledge for the emerging institutional nature conservation in Hungary was decisive. He also took up leading public duties in the university (head of the institute, deputy dean) and in various scientific bodies. His contributions to nature conservation and education were acknowledged by several awards. After his retirement in 1996, as Professor Emeritus he remained active almost until his last days. On top of all these, his unmatched influence is greatly due to his friendly personality. He treated life with a very special serenity, his manner was direct, and he helped everyone selflessly. Having a good sense of humour, storytelling and singing, he was always in the heart of a community. Generations of botanists preserve his memory and build on the knowledge he collected and transferred to so many. 